\title{
The Nineteenth Century American Promenade. Precedent and Form
}

\author{
Wendy R. Jacobson \\ Virginia Polytechnic Institute and State University, United States of America \\ School of Architecture + Design, Landscape Architecture Program \\ wjacobso@vt.edu
}

\begin{abstract}
The promenade became firmly established in Europe as a public space type in the seventeenth and eighteenth centuries, appearing on the North American continent in the late eighteenth century. By the mid-nineteenth century a number of American cities offered designated outdoor settings for citizens to engage the social practice of "seeing and being seen", in locations as diverse as cemeteries, fashionable streets, waterfront embankments, resort beachfronts, and later, in urban parks and along parkways. These public spaces attracted diverse populations, from working and middle classes to social elites, fulfilling a range of social and recreational goals in a variety of contexts. The promenade has endured as a highly popular public space type over many generations and across diverse cultural and geographic contexts, prompting the question whether there are certain formal qualities that have enhanced the success of the promenade as a public space? Are there are particular physical and spatial conditions that have persisted, contributing to its capacity to endure?

This paper describes the evolution of urban promenades in Western Europe and in the United States from the sixteenth to nineteenth centuries, before applying typological analysis to a set of promenade precedents drawn from several countries and across a span of several hundred years. The analysis reveals that factors such as location, connectivity, adjacency, alignment, dimensions, scale, and amenity features have contributed to the qualities of accessibility, activity, and comfort that have attracted people to promenades and supported their popularity over time. The paper concludes that nineteenth century American promenades were legitimate successors to earlier European precedents, exhibiting similarities in physical and spatial attributes that place them squarely within a typological tradition.
\end{abstract}

Keywords: urban promenade; public space type; nineteenth century America

\section{To cite this article:}

Jacobson W. (2017). The Nineteenth Century American Promenade. Precedent and Form. The Journal of Public Space, 2(4), 37-62. DOI: 10.5204/jps.v2i4. 140

This article has been peer-reviewed and accepted for publication in The Journal of Public Space. Please see the Editorial Policies under the 'About' section of the journal website for further information. 


\section{Introduction}

Used as a verb, the word "promenade" connotes the act of walking leisurely in a social setting; employed as a noun, the word refers to the setting for that activity. The practice of promenading and the provision of designated settings to accommodate this activity has a lengthy history, becoming firmly established in Europe in the seventeenth and eighteenth centuries, and appearing on the North American continent in the late eighteenth century. By the mid-nineteenth century a number of American cities boasted outdoor settings for citizens to engage the social practice of "seeing and being seen", while enjoying a casual stroll along comfortably scaled, shaded pathways. Promenades were found in cemeteries, along popular streets, beside water reservoirs and embankments, along resort beachfronts, and eventually, in urban parks as well (Bluestone, 1987). They fulfilled a range of social and recreational goals, in a variety of social contexts. For affluent upper class residents, the promenade offered an alternative social setting to the formal parlor or the structured social event. While still constrained by a highly disciplined code of conduct, the promenade could yet function as a venue for sedate recreation and entertainment, for social encounter, and not least, for validation of social status. For the middle and lower classes, the expectation was that the opportunity of strolling among their "betters" would educate them in the manners and cultural mores that exemplified the highest ideals of an increasingly heterogeneous society, inspiring social cohesion and civic pride (Bluestone, 1987). And as early as the nineteenth century, some social reformers saw another desirable outcome of public promenading, urging working class Americans to take up the practice of walking as a healthful activity (Malone and Parrott, 1998).

Promenades remained popular public spaces in many American cities until the twentieth century, when changes in social mores and the withdrawal of middle classes to domestic suburban realms diminished the popularity of public promenading as a social pursuit. At the same time many street-related promenade spaces fell victim to functionalist planning doctrine that privileged the role of city streets as traffic corridors over their traditional function as places of social encounter. However urban revitalization efforts that occurred in the latter part of the twentieth century brought renewed recognition of the value of public space in general and linear promenades in particular, as important social and recreational resources. Especially noteworthy was the rebirth of the promenade on waterfronts throughout the United States, as cities reclaimed formerly inaccessible and uninviting post-industrial landscapes and transformed them into prized public space assets. The promenade has endured as a highly popular public space type over many generations and across diverse cultural and geographic contexts, prompting the question whether there are certain formal qualities that enhance accessibility, activity, and amenity, and therefore contribute to the success of the promenade as a public space? Are there are particular physical and spatial conditions that have persisted, contributing to the capacity of the promenade to endure over centuries? And ultimately, could the success of contemporary American promenades be attributed in part to typological factors that are shared with eighteenth century and nineteenth century antecedents? This paper explores the first two questions, with a view to establishing the basis for future study comparing nineteenth century American precedents to the twentieth century waterfront promenades that succeeded them.

Promenades in nineteenth century American cities and the social practices that characterized them have been the subject of considerable historical research (Bluestone, 1987; Monosh, 1998; Scobey, 1992). The physical and spatial characteristics of early European and American promenades have also been described in urban design histories 
(Girouard, 1985; Kostof, 199I) and in studies of particular historic precedents (Cleary, 2002; Darin, 2000; Larkham, 2000; Macdonald, 2012; Malone and Parrott, 1998; Rabreau, 1991; Reps, 1991). However few studies have compared spatial attributes of promenades from different eras. This paper examines typological characteristics of nineteenth century American urban promenades, comparing them to earlier European precedents, with a view to identifying features that contributed to their success as lively public spaces, features that may well have established a legacy for twentieth century promenades. Since designers of early American promenades were themselves indebted to centuries of European precedents for formal inspiration, the paper begins with an overview of the historical evolution of promenades in Europe and England, before shifting focus to examine the development of the promenade in the United States in the eighteenth and nineteenth centuries. Similarly, analysis of typological features originates with selected European precedents as a means of assessing the provenance of formal characteristics of the promenades that appeared subsequently in American cities. Since the study aims to relate physical and spatial conditions that characterized promenades to their success in supporting public life, precedents were selected based on contemporary accounts of levels of use. Thus promenades that were highly popular and regularly attracted large numbers of people were deemed representative of successful public spaces in their respective eras.

The research employs typological analysis, meaning the study of physical and spatial qualities of a particular type (in this case a public space type, the promenade) with the aim of identifying features that are held in common and define the type as a set of elements with shared traits. Typological analysis may be focused on study of characteristics shared by urban elements within a particular time period (synchronic) or across different periods (diachronic) (Moudon, 1987). This study adopts a diachronic approach, in response to the question of whether there are particular physical and spatial conditions that have typified the promenade over centuries, and thus may have contributed to its success as an enduring public space type.

\section{Evolution of the Promenade: European precedents}

Mediterranean populations in Southern Europe have long been known for their formal evening ritual of walking along the paseo, the esplanada, or the corso. The Northern European equivalent, the promenade, first appeared in France in the late 15C, apparently borrowed from earlier Italian precedents. A planted walk was created outside the boundary wall of the French city of Tours to afford a playing ground for the Italian game of pollo a maglio, which was translated into French as "pail-mail" and eventually into English as "pall mall" (Darin, 2000; Girouard, 1985). A predecessor of the contemporary game of croquet, pall mall required a long corridor through which to propel a ball, and for the comfort of the players it was lined with shade trees. In the early seventeenth century a similar mall was created near the Arsenal in Paris, in this case bordered by a parallel tree-lined avenue for spectators to perambulate and to observe the game (Poete, cited in Girouard, 1985). 


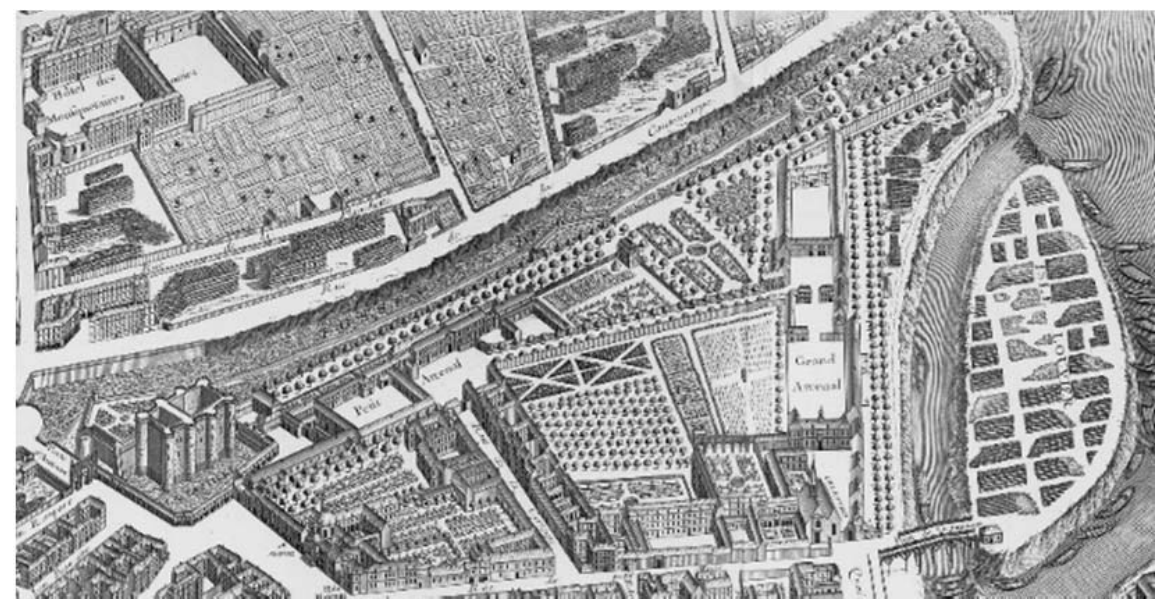

Fig. I. View of the Arsenal Mall, Turgot map of Paris, 1739.

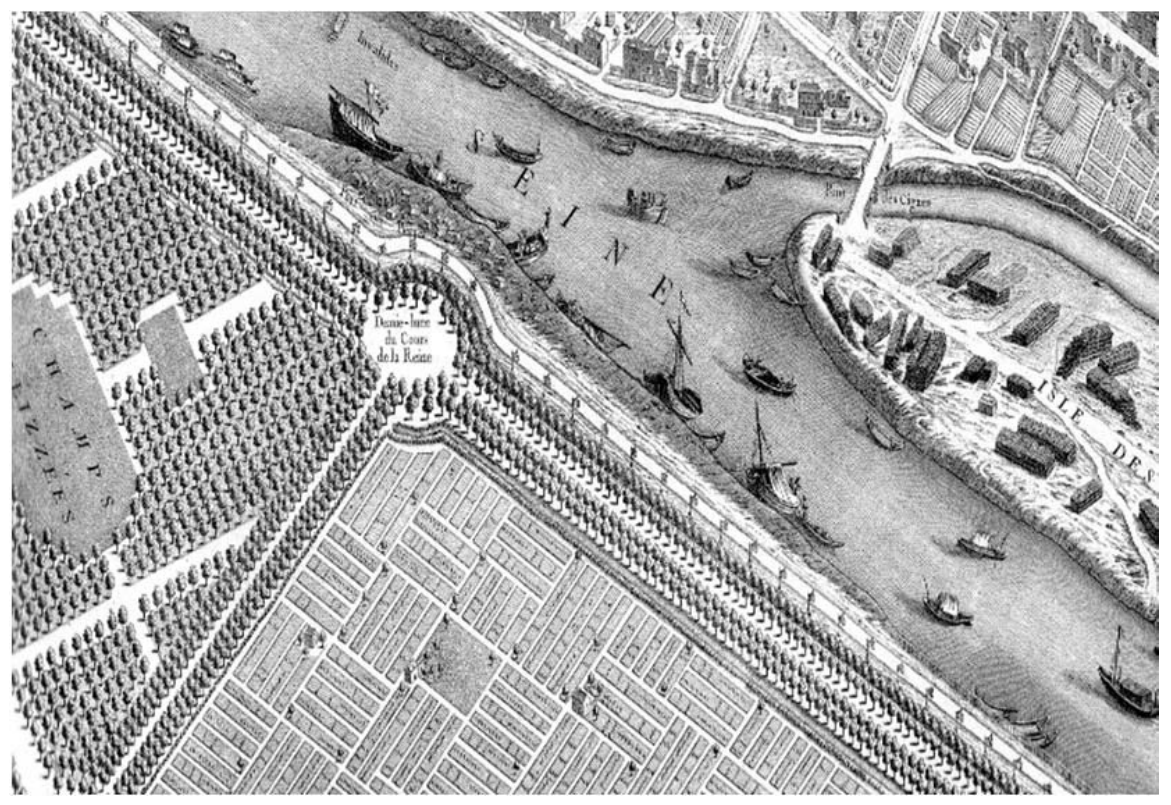

Fig. 2. Aerial view of Cours la Reine, bordering the Seine River, Paris. Turgot map of Paris, 1739.

The Arsenal mall became a desirable venue for social display by Parisian aristocrats, a corollary to the hugely popular Cours la Reine, a tree-lined triple avenue located adjacent to the Seine River where thousands of carriages paraded in the summer evenings. Similar street promenades were laid out in other parts of Paris to accommodate the daily social ritual of seeing and being seen on the part of upper class patrons in their carriages, as well as by the middle and lower classes, who attended on foot.

As an alternative to the street promenade the garden allee, consisting of a heavily shaded linear pathway within a private, park-like setting, was also favored by the upper classes (Lawrence, 1988). The exemplary redesign of the Tuileries gardens by Andre le Notre in the mid seventeenth century afforded fashionable aristocrats a wide central walkway, shaded by trees and flanked on either side by lesser paths. Evidently it was not uncommon for the occupants of carriages to first circulate on the adjacent Cours la Reine before alighting to stroll along the pedestrian promenade within the Tuileries garden in the evening hours (Girouard, 1985). This concourse was later extended outside the 
garden to form the Avenue des Tuileries, a precursor to the nineteenth century Avenue des Champs Elysee (Kostof, 1991).

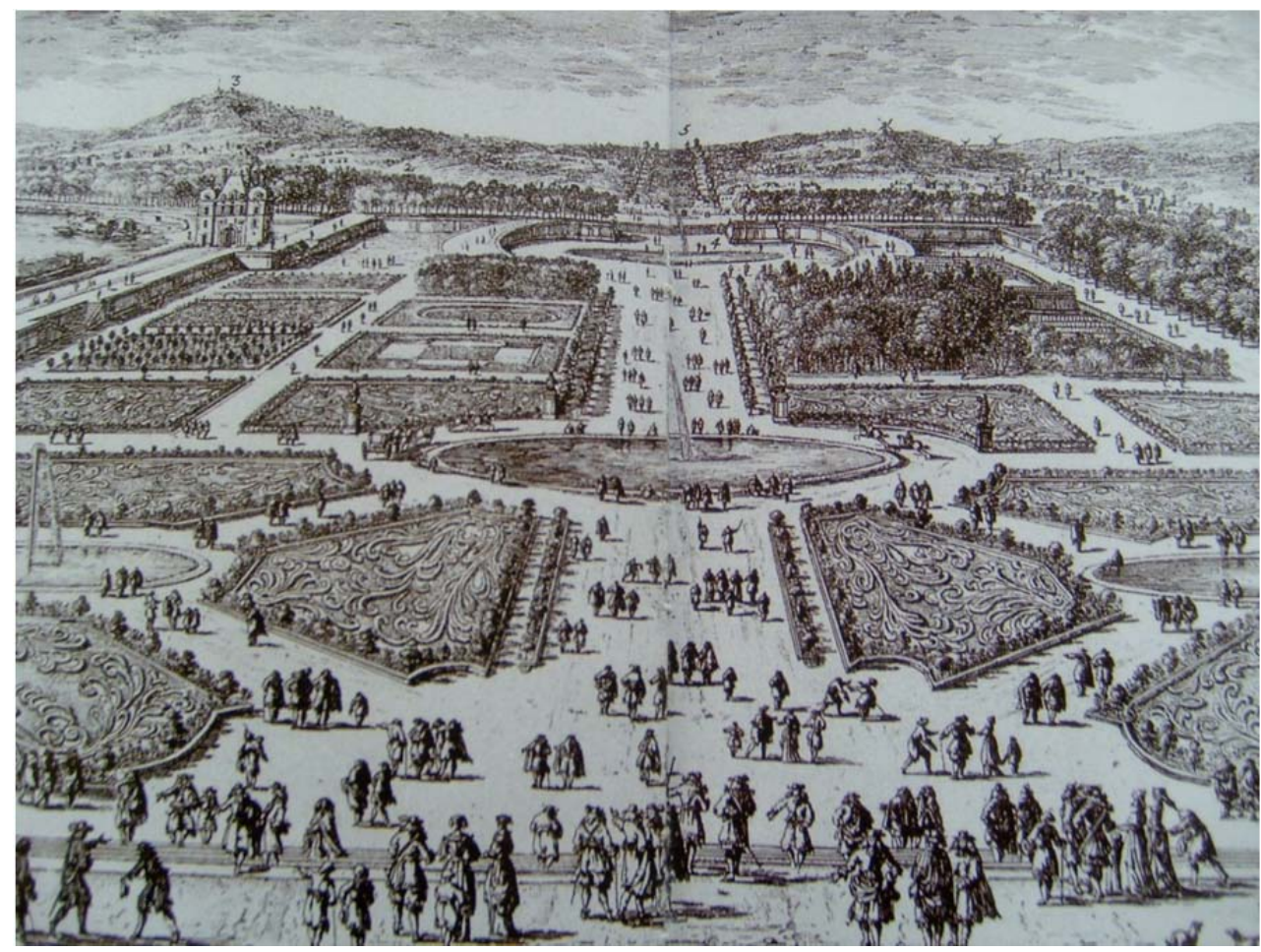

Fig. 3. View of central promenade in Tuileries Garden, Paris I8C. Engraving by Perelle.

Meantime in provincial French cities such as Orleans and Avignon, promenades had been created along the outsides of perimeter city walls or atop the sites of former fortifications (Darin, 2000). In Paris the popularity of the Arsenal mall and the Cours la Reine prompted establishment of tree-lined promenades on the city's elevated ramparts that had been made obsolete in the late 1600s as military defense tactics changed (Kostof, 199I). A typical rampart, or "belt", boulevard consisted of a wide tree-lined central drive for carriages, with generous shaded walkways on either side for pedestrian promenading (Girouard, 1985), although in some cases the promenade occupied a central median. As French cities developed further in the nineteenth century, the belt boulevards became major thoroughfares, and in some cases, prestigious addresses for the wealthy. In Paris in particular, the early ring promenades furnished precedents for the Grands Boulevards of the seventeenth century, and later the famous nineteenth century boulevards that became the most identifiable formal elements of the Parisian street pattern following the restructuring of the city by Baron Haussmann. However as Darin (2000) points out, the generous dimensions of these boulevards, their connectivity, and their effectiveness in accommodating traffic flows ultimately led to their demise as convivial pedestrian realms by the twentieth century, many sidewalks had been narrowed and central tree-lined medians removed to allow for expanded traffic lanes and parking areas.

By the late seventeenth century the popularity of the French promenade as a social venue had also spread to Britain, where the term "parade" was coined to differentiate a carriageway used for social activity from a promenade, which referred to a path frequented by pedestrians. Both the parade and the promenade were settings where 
people met at a particular time of day solely for the purpose of social engagement, whether for display, orchestrated meeting, or casual encounter. London had its Mall in St. James Park, which like the Arsenal in Paris, was originally established to accommodate the game of pall mall, but later became a promenade frequented by fashionable society at specific times of day. Many provincial English towns provided similar, if less grand settings for the parade or promenade to take place (Girouard, 1985).

London also became known for promenading opportunities in its pleasure gardens in the eighteenth century. These were park-like settings with pleasant walks, interspersed with bandstands, refreshment booths, and other structures where entertainments were staged (Girouard, 1985). The pleasure garden could be considered a precursor to the eighteenth century health resort, where wealthy patrons gathered to take mineral waters for health, to enjoy a full program of scheduled entertainment, and to participate in necessary rituals of social display and engagement. The promenade was an all-important spatial setting in the health resort, and all major spas boasted scenic walks where one could perambulate, linger, and observe others in similar pursuits. Seaside resorts too, developed not long after the advent of the English spa towns. By the mid I800's the marine promenade had become a fixture of the seaside resort, the city of Brighton boasting a four-mile long pedestrian walkway bordering the shoreline, with a parallel carriageway (Girouard, 1985).

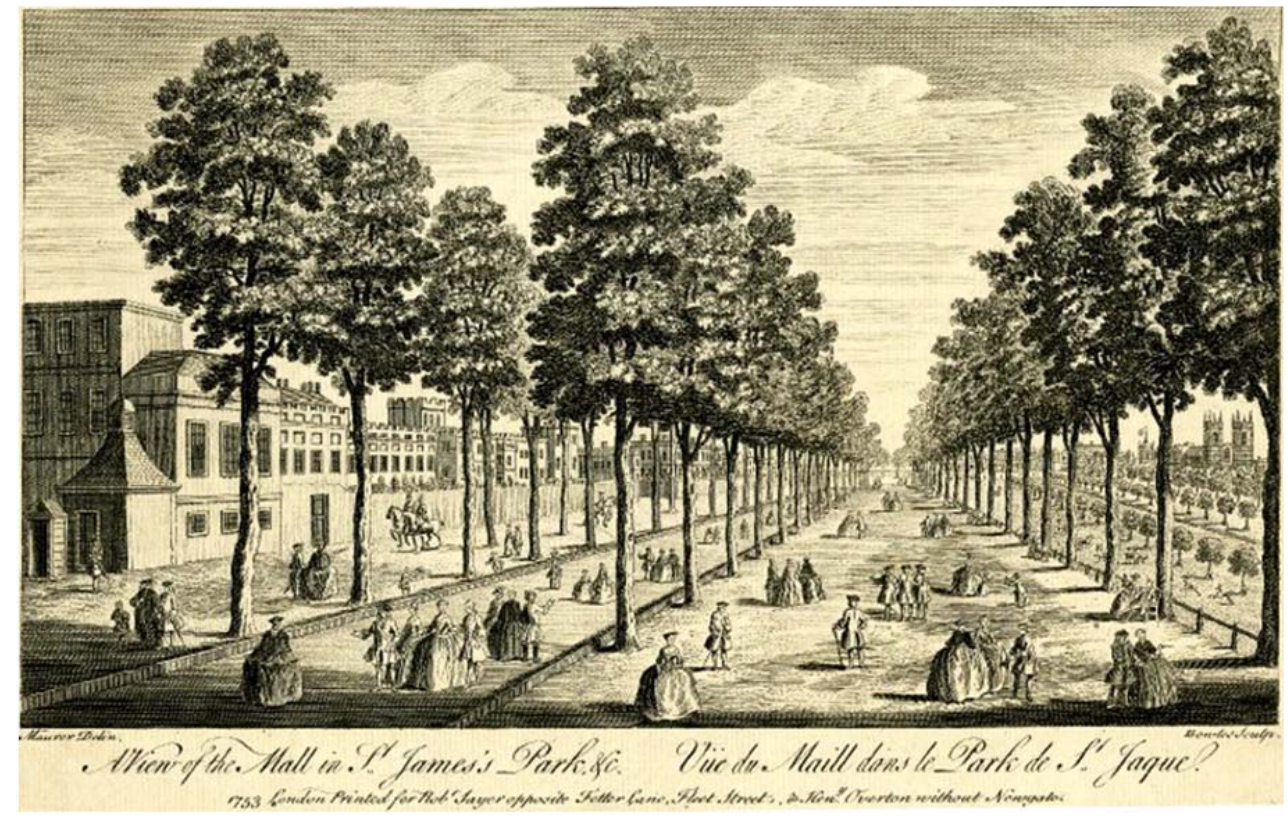

Fig. 4. I8C view of the Mall in St. James Park, which succeeded the original pall mall ground and promenade in St. James field.

\section{Eighteenth and Nineteenth Century American Promenades}

In the United States Pierre L'Enfant, undoubtedly familiar with pedestrian mall precedents in contemporary Paris and London, proposed a grand tree-lined central public walkway that came to be known as "The Mall", as a key feature of his I79I plan for the city of Washington DC. L'Enfant intended the Mall, which linked the President's House and the Capitol Building, to be an active public space, accommodating grand public buildings, educational and amenity functions - a national promenade to promote democratic engagement among citizens of the new republic. In Boston as well, by the late I700's a 
half-mile long tree-lined promenade known as the "Mall" had been created along the eastern frontage of the Boston Common, while a smaller walkway, also lined with shade trees, was located along the Park Street boundary. Within a couple of decades these promenades were extended to encompass the entire perimeter of the Common.

According to contemporary observers, these walks offered fine views of the bay and the adjacent Common, and they were also favored with refreshing breezes from the nearby waterfront (Domosh, 1996).

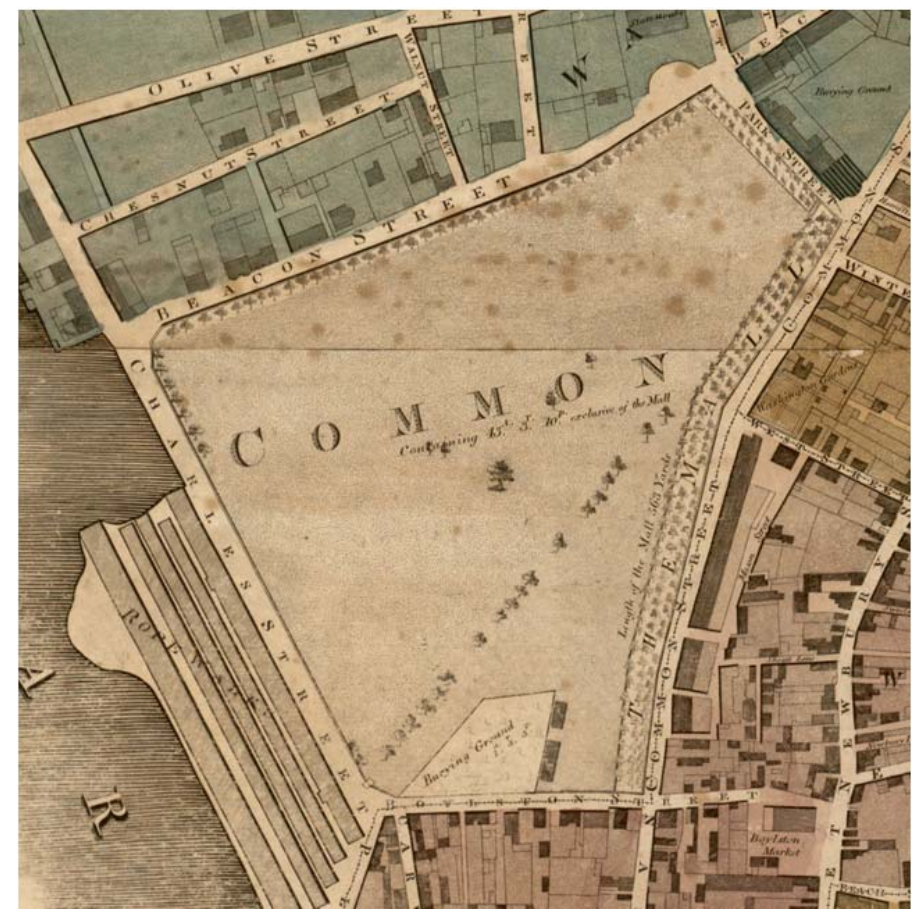

Fig. 5. Detail of 1814 map of Boston by John Groves Hale, showing the Mall along the eastern boundary of Boston Common and adjoining promenades along Park and Beacon Streets.

Only a few decades later influential public figures like William Cullen Bryant and Frederick Law Olmsted would write eloquently of the virtues of European promenades that they had visited, urging the creation of more public pedestrian concourses in American cities. Soon pedestrian promenades and "parkways" accommodating both carriages and pedestrians appeared (Bluestone, 1987). Some, like the tree-lined promenades that were developed in the mid-1800's along the canals in the textile manufacturing town of Lowell, Massachusetts, were populated by all levels of society. The Lowell canalside walks were created by local industrialists in part, to recruit and retain workers with the offer of pleasant and healthful settings to enjoy on Sundays, their sole day of leisure (Malone and Parrott, 1998). In larger cities as well, working class people were welcome to participate in the social engagement of certain promenades, however at other, more elite venues they were expected to be passive spectators. Scobey (1992) contrasts the often raucous plebeian culture of New York's Bowery promenade with the highly disciplined rituals of social engagement enacted by upper class New Yorkers as they paraded along Broadway and Fifth Avenues at specific times of the day. While socializing between upper and lower classes was discouraged in these elite venues, the presence of an audience of lesser status individuals was actually desirable, to witness and thereby legitimize the gentry's display of "ascendance over the whole social order" (Scobey, 1992: 221). 


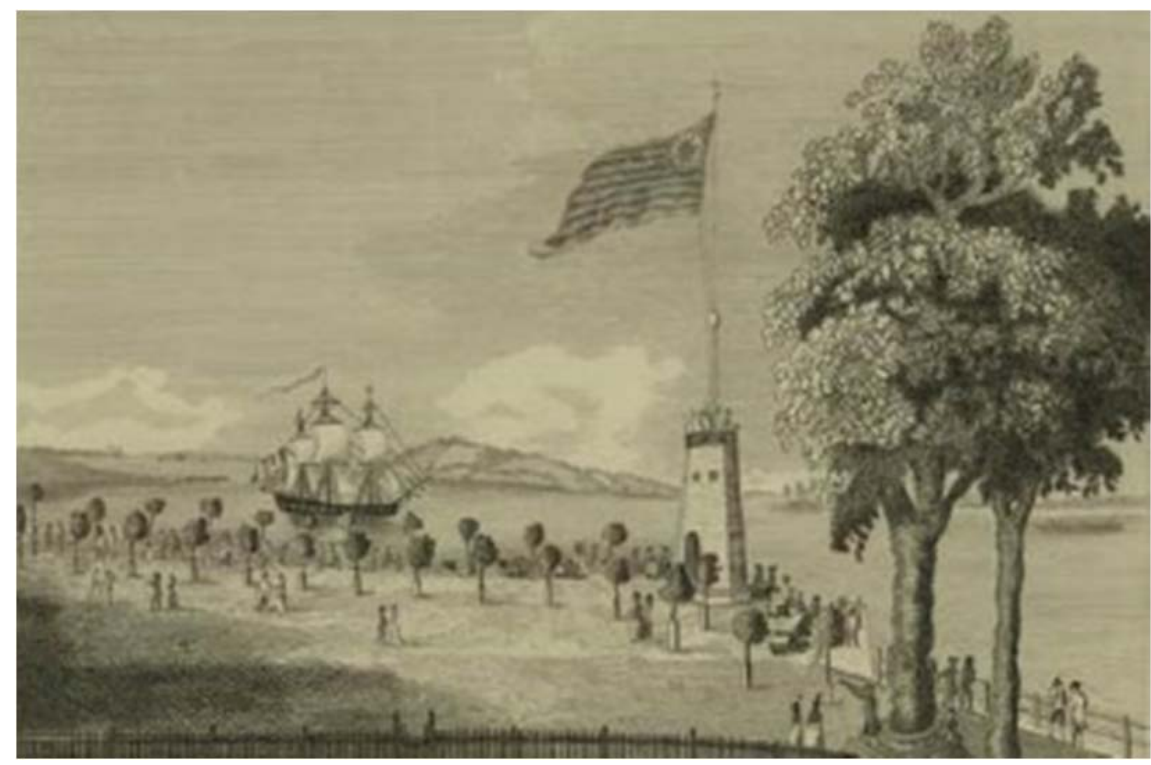

Fig. 6. Early view of the Battery Promenade, New York City, late I8C.

In Brooklyn an informal promenade developed through the 1820's-1840's along Brooklyn Heights, overlooking the East River and the bustling port of New York. Another was established in 1847 at Fort Greene, a Revolutionary War site, where a hilltop plaza provided excellent views and a fitting terminus for the walk. Waterfront views were also a key attraction of the popular Battery promenade, which had been established in the late 1700s at the southern tip of Manhattan on the site of another colonial fortification that was rendered obsolete after the Revolutionary War. Other public walks emerged informally in cemeteries, and along the flat terraces that bordered reservoirs and waterfront embankments. These spacious settings, with their shade trees and pleasing landscape views, offered welcome relief from dirty, crowded city streets. The late nineteenth century also saw the development of recreational venues such as Coney Island, where a boardwalk promenade lined with hotels, music stands and other amusements lured visitors to a setting more commercial than pastoral, an early precedent for other beachfront boardwalks in nearby resort towns (Bluestone, 1987).

By the latter part of the nineteenth century, a promenade also appeared as a key design feature of Central Park, Frederick Law Olmsted's great contribution to the legacy of public space in the city of New York. While the park on the whole was intended to be a setting where the experience of nature should rejuvenate city dwellers physically, mentally and spiritually, the grand Mall in Central Park in contrast was envisioned by Olmsted as a "gregarious" space. As such, it should attract large numbers of people of all classes to observe and engage the public life of the city (Bluestone, 1987). He similarly proposed for Prospect Park a space where:

Men must come together, and must be seen coming together, in carriages, on horseback and on foot, and the concourse of animated life which will thus be formed, must in itself be made, if possible, an attractive and diverting spectacle (Olmsted, quoted in Bluestone, 1987: 531). 


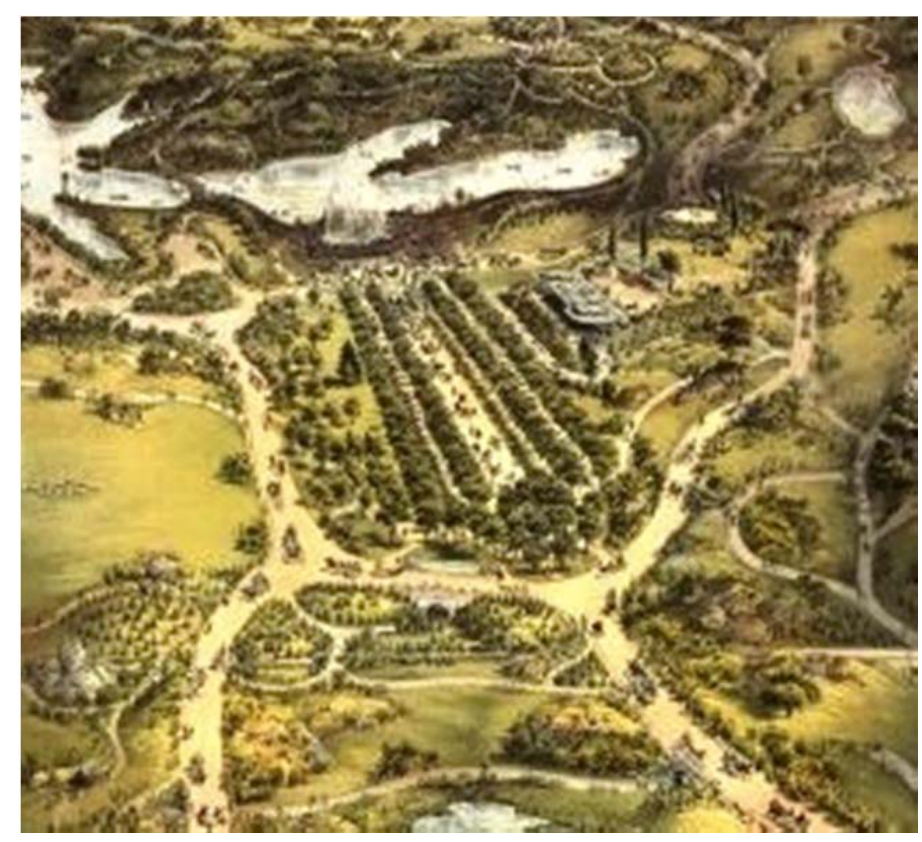

Fig. 7. View of the Mall, Central Park. John Bachman, 1858.

Olmsted was also responsible for introducing to the United States street-related promenades modelled after Parisian boulevards. By the 1870s his Eastern Parkway, with its central carriageway and parallel pedestrian concourses, stretched from Brooklyn's Prospect Park to Ralph Avenue, and its corollary, Oceanview Boulevard, had become an established amenity feature linking Prospect Park with Coney Island. Olmsted intended that these scenic routes would connect various local parks to form a larger network spanning Brooklyn and Manhattan, although the system was far less extensive in scope as ultimately constructed. Parkways designed by Olmsted also appeared in cities such as Buffalo, Boston, and Louisville in the latter part of the nineteenth century (Macdonald, 20I2).

Nineteenth century American promenades performed important functions. With their shaded concourses, landscaped environs, fresh air, and pleasant views, they offered respite from the crowded, unhealthy conditions that characterized rapidly industrializing cities. However, as important were the social functions that they supported. In addition to its role as a fashionable entertainment, for the elite classes promenading according to highly orchestrated rituals of display and interaction contributed to a shared sense of class identity (Scobey, 1992). But the promenade was viewed equally by civic leaders as an educational venue where those of lower social status could observe and emulate the manners and cultural mores of their "betters". In an increasingly heterogeneous American society, there was a strong impetus to foster unity and shared cultural values as a strategy for achieving greater social cohesion, and with it, social stability (Bluestone, 1987). Somewhat perversely, the achievement of social cohesion was predicated on clear demarcation of class boundaries in many promenades, and thus while the goal was nominally egalitarian in purpose, the apparent outcome was to visibly reinforce elitist social stratification.

Ultimately the popularity of formal promenades on fashionable streets was overtaken by promenading activities in the newly created public parks and boulevards of mid to late nineteenth century America, venues that were open to, and frequented by all classes of 
people. By the turn of the twentieth century the act of formal promenading according to rigidly prescribed rules of decorum had declined, as its genteel actors turned to other, more private institutional settings such as clubs, fraternities, and learned societies to socialize. At the same time, working class people began to appropriate streets and other promenade spaces for their own recreational pursuits as well as for workers' parades, labor demonstrations, and other expressions of political sentiment (Scobey, 1992). However the promenades in New York's public parks and the boardwalks at Coney Island and other beachfront resort venues continued to attract throngs of recreational pleasure-seekers, and the Brooklyn parkways remained popular social spaces for the diverse neighborhoods that bordered them.

The introduction of a functionalist approach to urban design in the mid twentieth century challenged the role of the street as a social space. The architect Le Corbusier, a key proponent of the Modernist city, promoted a vision of the street as a "machine for traffic" (le Corbusier, 1929) dedicated to efficient movement of vehicles, with pedestrians ideally grade-separated from this activity. Public spaces were also envisioned in functionalist terms; their role was to provide greenery, fresh air and sunlight, with little acknowledgement of the need for outdoor spaces to support social encounters among the people who frequented them. This vision was realized most dramatically in the reconfiguring of many American city streets and urban parkways, to facilitate efficient channeling of automobile traffic. Public parks as well were subject to functionalist revision at this time. The social experiment symbolized by the mingling of young and old, rich and poor, immigrant and established elite on park promenades and in informal landscaped settings, was relinquished in favor of a new vision of active recreation and programmed activity targeting the physical health and fitness of city dwellers. Thus not only did the impetus for the practice of promenading dissipate with the changed socio-political context of the late nineteenth century, many of the physical settings for this act of public engagement were also systematically eliminated by the mid twentieth century, as a result of the zealous transformation of the pre-industrial city to its modernist incarnation. While conventions for the use of urban promenades varied greatly across generations and continents, the popularity of this public space type as a venue for social representation and engagement persisted until the twentieth century brought a general devaluing of the social dimension of the public realm as an outcome of functionalist/modernist planning doctrine. Nonetheless the endurance of the promenade over time suggests that certain physical and spatial characteristics common across the type may be in part responsible for its success in supporting social interactions among disparate populations in very different social contexts. Study of promenade precedents that are acknowledged to have been popular sites for social engagement in different eras and different cultures, shows some similarities with regard to location, connectivity, adjacency, alignment, spatial characteristics, scale, and amenity features. For example, a promenade that was well connected to local streets would benefit by enhanced accessibility to neighboring populations, while connections to through routes could negatively impact the tranquility of the setting. The nature of adjacent land uses could influence the number and type of residents or visitors who were likely to populate the promenade, while alignment, dimensions, scale and amenity features could affect the continuity, comfort, and pleasure of the promenade experience. The following section explores these conditions in selected European and American precedents, with a particular focus on nineteenth century American promenades. 


\section{Spatial Characteristics of Eighteenth and Nineteenth Century Urban Promenades}

As the practice of promenading became more popular as a social pastime, locations shifted from countryside settings to urban venues that were much more accessible to people who could not afford carriage travel. Early French promenades associated with the game of pall-mall were situated in locations where long, straight stretches of open ground were available to accommodate play, generally just outside the city walls. Other promenades soon appeared alongside city walls or on top of ramparts, which offered wide, flat, elevated, unbuilt ground with good views and ideal conditions for leisurely walking or slow circulation on horseback or by carriage. As former defensive fortifications, the ramparts encircled the city and the combined carriageways and treelined pedestrian promenades that were established in these locations formed circuits, hence the "belt", or "ring" boulevard designation. The circular alignment afforded an ideal configuration for strolling, since it was continuous and given sufficient time, promenaders could return to their departure points without reversing direction, while enjoying everchanging views. Benefiting from restricted through traffic but easy connections to nearby affluent neighborhoods, belt boulevards were popular venues for promenading. Over time however, first the city sides of many rampart boulevards and then the outward sides were developed, so that residential and commercial buildings came to line both sides of the corridors. The resultant increase in local traffic and obstruction of views diminished the amenity value of the belt boulevard promenades and Cleary (2002) notes that eventually they transformed to function as city streets rather than linear public spaces. In Paris, boulevard promenades were later created on streets that were situated within easy access of fashionable neighborhoods, and the amenity value associated with their presence often stimulated land development on bordering lots. All were designed as selfcontained, linear public spaces that, while connected to and accessible from the surrounding street system, were not intended as through routes to link external destinations.

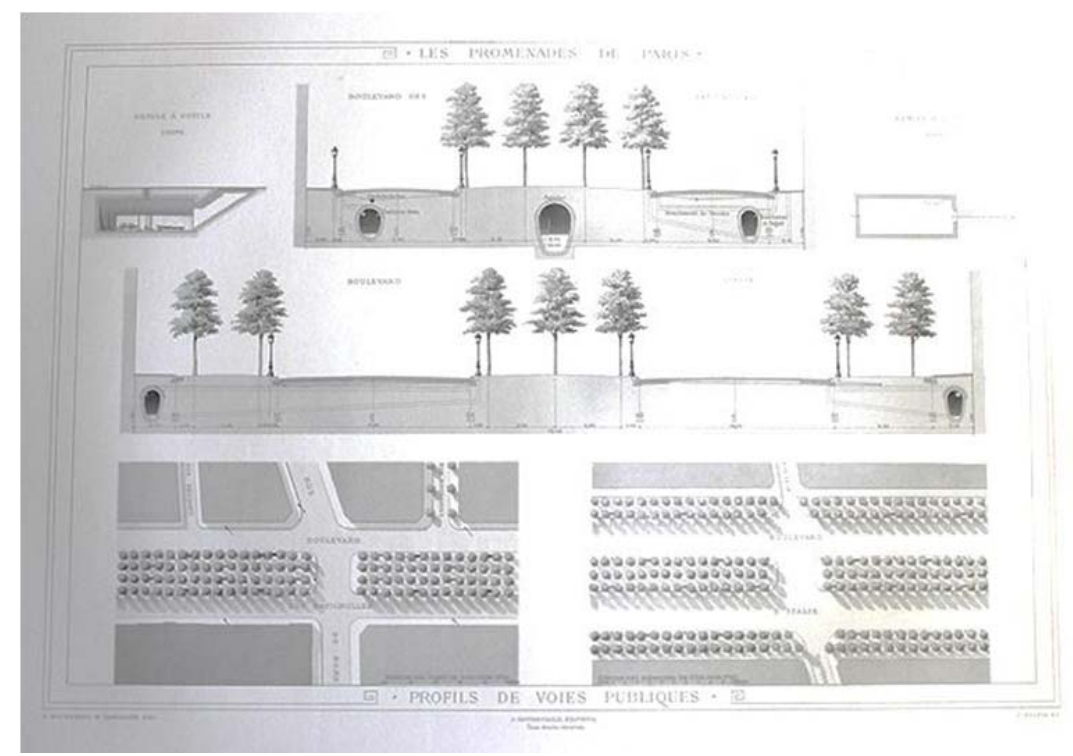

Fig. 8. Plan and section drawings of Boulevards des Batignolles and Italies. Les Promenades de Paris. JeanCharles-Aldolphe Alphand, 1867-73. 
This ensured that the amenity of both adjacent residents and recreational users of the promenades would be maintained. This condition changed with the establishment of a citywide network of boulevards by Baron Haussmann in the nineteenth century. Although these streets were designed with grand dimensions and ample amenity to serve fashionable carriage and pedestrian promenaders, they were intended equally to function as critical connectors in a modernized street system, cutting through dense urban fabric to enable goods to be transported efficiently from points of manufacture to train terminals, and to facilitate the rapid movement of police and military personnel throughout the city at a time when civil unrest was a pressing concern (Rogers, 200I). Some of the boulevards were also intended to stimulate new residential development in what were at the time peripheral areas of the city.

The specific physical attributes of each of the Haussmann boulevards were systematically prescribed in both plan and section drawings in the landmark urban design handbook compiled by Jean-Charles Adolphe Alphand, entitled Les Promenades de Paris (Alphand, 1867). These drawings identified the precise locations and dimensions of carriageways, tree boulevards, walkways, light standards and other street furniture, as well as underground utilities. Importantly, height limits and setback requirements were also prescribed for buildings that lined the boulevards in order to maintain a comfortable pedestrian scale, with building height varying according to a set ratio based on the width of the street. The boulevards became highly desirable locations for both upper level residential and street level commercial uses, and adjacent properties were consistently developed with buildings of up to five storeys, significantly increasing the resident population with direct access to the lively pedestrian realm on the street below. In addition to generous tree planting, the boulevards were furnished with gaslights, benches, news kiosks, and other amenity features designed to enhance comfort and appeal for pedestrians.

Other European street promenades varied in form. Almost always generously dimensioned, some had central carriageways with parallel pedestrian concourses on either side while others, like the eighteenth century Gardiner's Mall in Dublin and Unter den Linden mall in Berlin, had wide, tree-lined central malls reserved for pedestrians, with flanking carriageways (Girouard, 1985). These broad pedestrian concourses offered ample space for sedate procession, and sufficient distance from the carriageways to ensure that discreet conversations would not be hindered by traffic noise. By the end of the eighteenth century garden promenades also had become common features in many European cities. In addition to the obligatory rows of shade trees, promenades that were situated in garden or park settings usually boasted more elaborate landscaping and more diverse views.

In Britain, early promenades were linear and like their Parisian counterparts, they were either pedestrian-only concourses, or if "parades" accommodating coaches, they were developed for the sole purpose of leisurely riding or strolling in society, seldom carrying through traffic since typically they were not well-connected to other destinations or to main circulation routes. Unlike the French belt boulevards that followed the circular alignment of earlier city walls, only a few early English promenades were built on or alongside former fortifications. Most were situated on undeveloped lands outside built-up city centers so as to offer pleasing views of the rural countryside, local woodlands, or natural water features. They adopted straight alignments, sometimes due to their provenance as the former sites of pall mall grounds, or possibly due to the influence of 
seventeenth century and eighteenth century garden designs in which long, straight avenues or allees bordered by trees offered popular promenading venues for elite classes (Larkham, 2000; Lawrence, 1988).

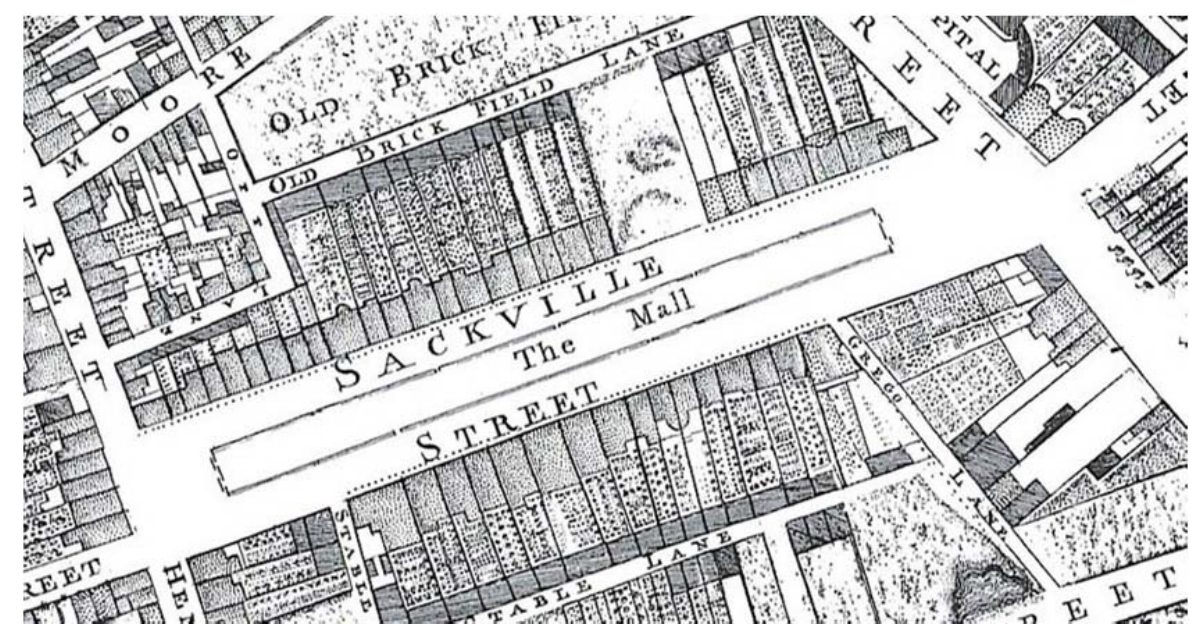

Fig. 9. Detail of Gardiner's Mall, Dublin, from An Exact Survey of the City and Suburbs of Dublin by John Roque, 1756.

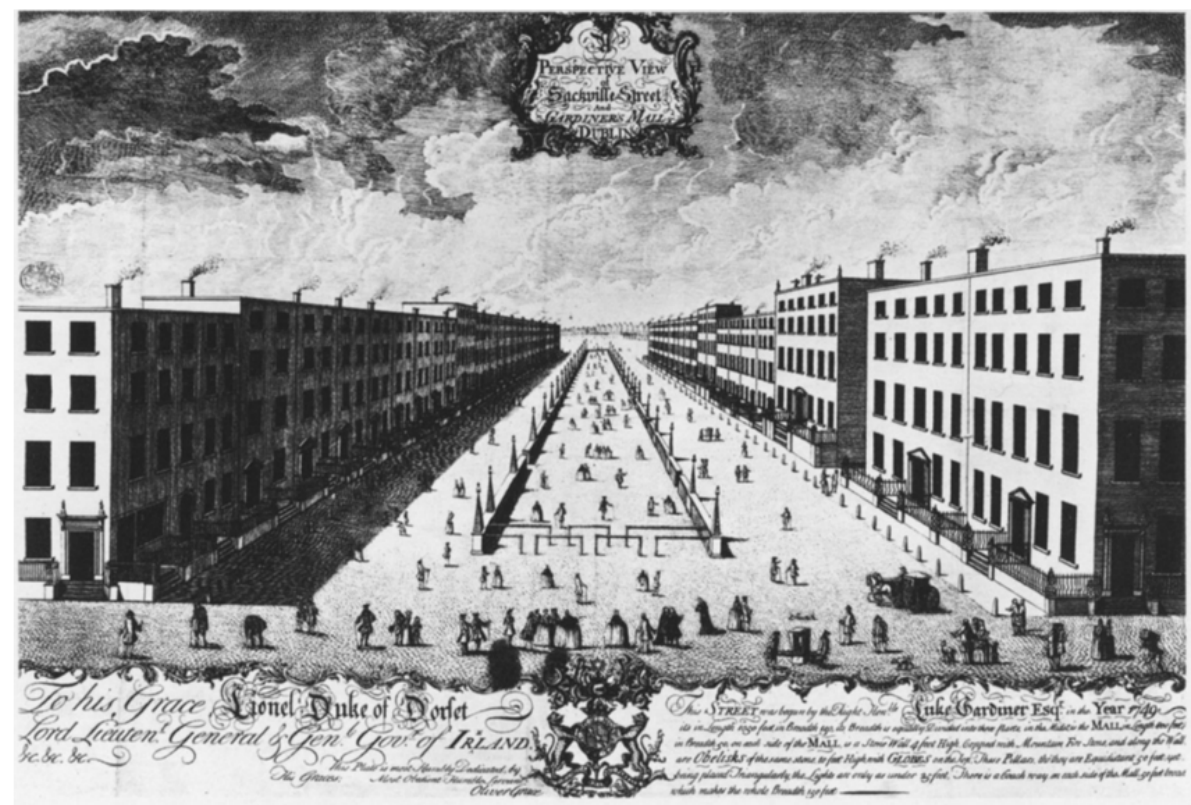

Fig. 10. Perspective view of Sackville Street and Gardiner's Mall in Dublin, Ireland in the 1750s, by Oliver Grace.

Promenades at English spa resorts were centrally located near the sites of the healing waters and their associated public rooms. However since the act of walking was considered to be a healthful supplement to the curative powers of the mineral waters, many spa promenades were designed to incorporate the presence of natural features, such as rural views. This is attested by the eighteenth century English novelist Fanny Burney, who wrote of the outlook from the Grand Parade in Bath: 
"We have meadows, hills, Prior Park, the soft-flowing Avon - whatever nature has to offer, I think, always in our view."

(Burney quoted in Girouard, 1985: 197)

Canalside, oceanfront or riverine promenades throughout seventeenth and eighteenth century Europe took their alignments from the configurations of the waterfronts that they bordered, and their amenity from proximity to the water, views across it, and often from fresh breezes emanating from it. Whether canalside or bordering quays, the rows of trees along these promenades were key amenity features that afforded not only visual benefits, but were thought to have health advantages as well, by cleansing the air of dangerous disease-causing vapors (Lawrence, 1988).

In the newly formed United States capital of Washington DC, Pierre L'Enfant's inclusion of a wide, straight, central pedestrian concourse flanked by carriageways in his 179I plan for the city, was almost certainly inspired by the conjoined garden and urban designs established in Versailles, France by Andre le Notre. L'Enfant had grown up in Versailles, and he would have been equally familiar with the grand pedestrian allees joining rond points, or points of intersection, in the famous gardens of Versailles, as with the wide, straight boulevards radiating from urban squares in the city plan (Rogers, 200I).

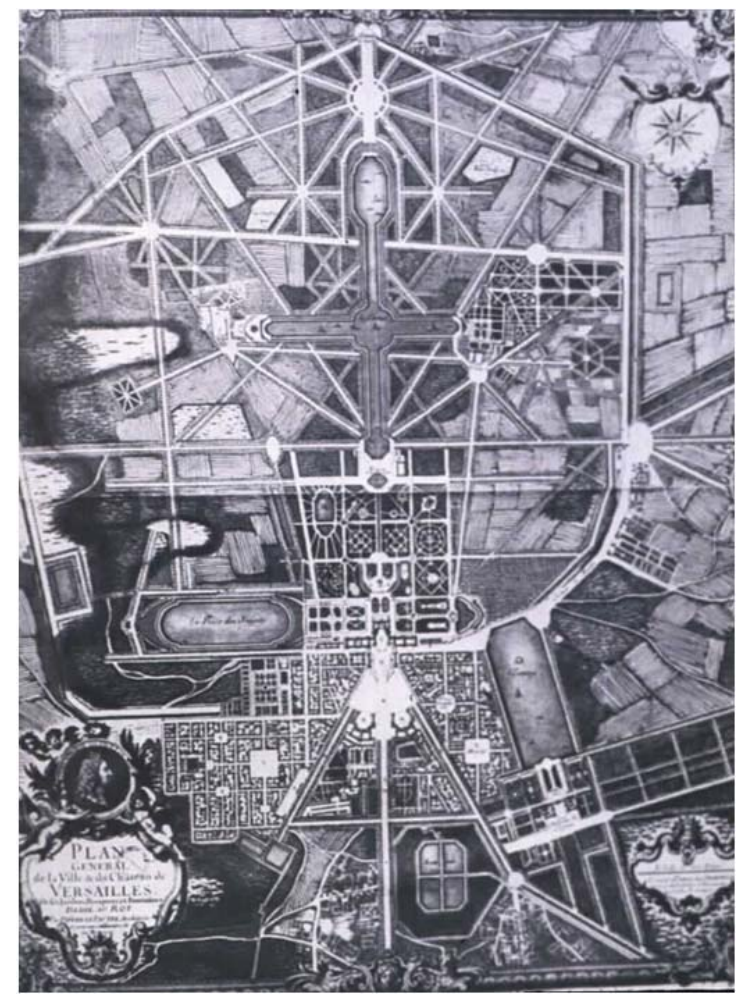

Fig. II. Plan of the City and Garden of Versailles designed by Andre le Notre, from an I8C engraving.

The Washington Mall was a unique gesture in a monumental urban plan. It was described by L'Enfant as a "Grand Avenue, 400 feet in breadth, and about a mile in length, bordered by gardens, ending in a slope from the houses on each side" (Reps, 1967:22). However it was not until the early years of the twentieth century that L'Enfant's vision for a linear 
public space of grand scale in the heart of the capital was realized, in the re-conceived Mall of the 190I Macmillan Plan, described as,

... an expanse of undulating green a mile and a half long and three hundred feet broad, walled on either side by elms, planted in formal procession four abreast. Bordering this green carpet, roads, park-like in character, stretch between Capitol and Monument, while beneath the elms one may walk or drive, protected from the sun.

(U.S. Senate Committee on the District of Columbia 1902, quoted in Reps, 1991: 252)

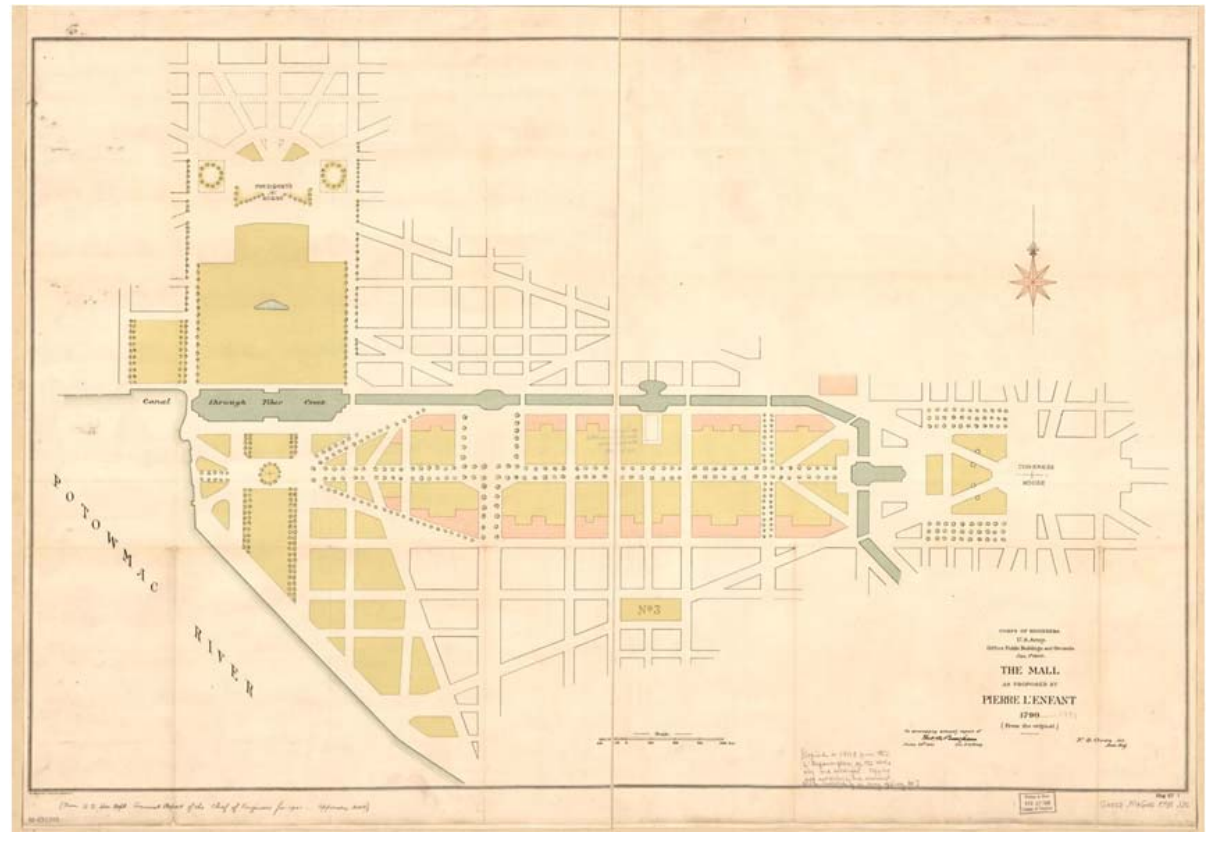

Fig. 12. The Mall in Washington DC, as proposed by Pierre L'Enfant 1790, from the original. Corps of Engineers, U.S. Army, Office of Public Buildings and Grounds, [190I].

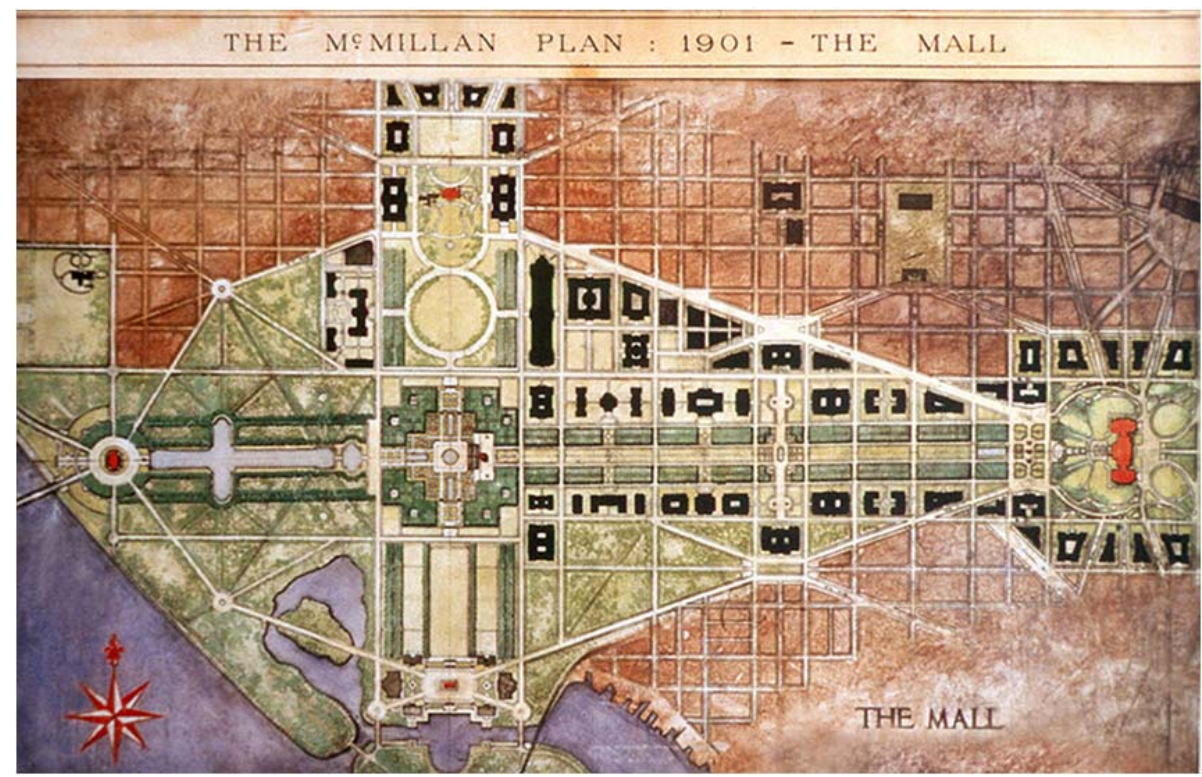

Fig. 13. McMillan Plan showing design for the Mall, Washington DC. 190I. 
The vast length and breadth of the Washington Mall was clearly intended to provide an impressive setting for the institutions of a new republic, and to accommodate enormous crowds on occasion, but despite its imposing scale the presence of green lawns and multiple rows of stately elm trees nevertheless afforded a congenial setting for individuals and small groups to make use of the space for leisurely promenades.

The tree-lined promenades that by 1816 encircled the entire Boston Common were of more modest width, but added together, their lengths approximated the mile and onehalf distance of their Washington counterpart, offering strollers a continuous circuit of generous extent. Their presence along the perimeter of the vast, open public green provided a clear delineation of the space and an effective transition from adjacent streets. Unlike the Washington Mall which fronted the nation's most important institutions and eventually became one of the most visited public spaces in the country, the Boston Common promenades were frequented mainly by local residents of nearby affluent neighborhoods. In later years, once landscape improvements had been made to the Common and a Public Garden established on an adjoining parcel to the west, the promenades became integral features of the larger park and the populations they attracted expanded accordingly.
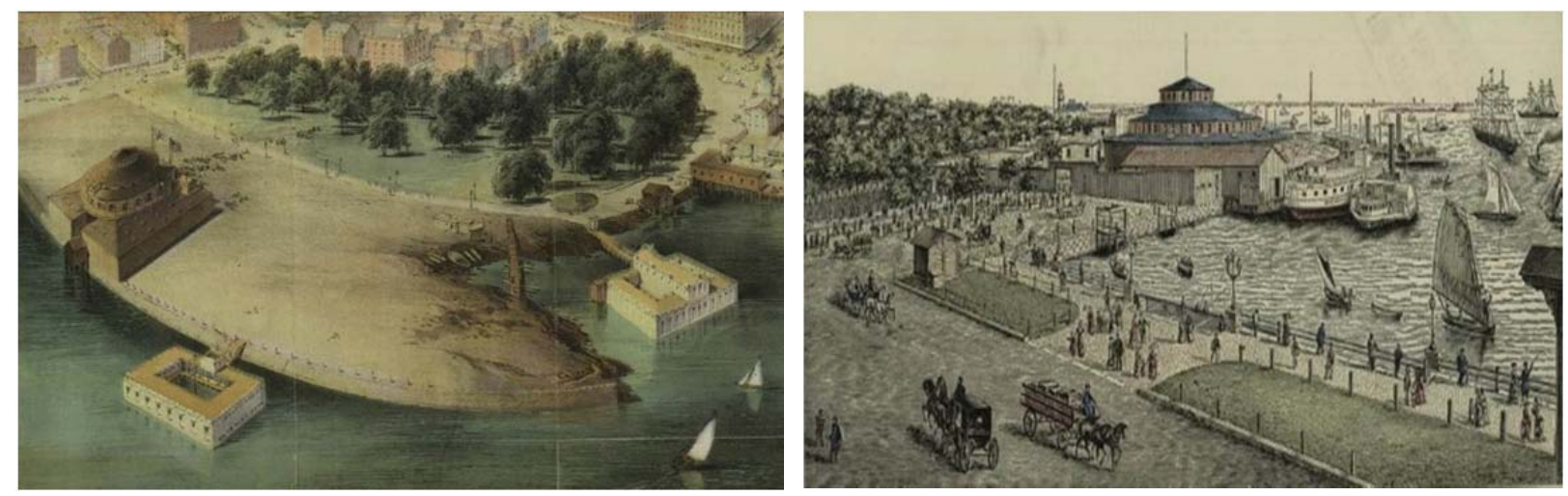

Fig. 14 (left). View of Battery Promenade (Castle Garden) showing filled area, New York City ca. 1869. Theodore August Liebler.

Fig. I5 (right). View of Battery promenade and immigrant embarkation center, New York City ca. 1869.

One of the earliest New York promenades, the eighteenth century Battery promenade was located on the southern tip of Manhattan, at the site of an early fortification. Initially a modest tree-lined linear walkway bordered on one side by the harbor and on the other by an open grassed area, by 1869 the park had been expanded to double its original size by filling at the shoreline, and a formal landscape with a network of curvilinear paths had been added to compliment a relocated waterfront concourse. Contemporary images show residential and commercial buildings on the park boundary, and a sizable immigrant landing center located centrally along the waterfront promenade at the site of the former fortification. These adjacencies account in part for the popularity of the Battery promenade with a wide range of populations, from working people to affluent upper classes. However its proximity to the water was another feature of great appeal - the presence of water and views across the harbor, coupled with the quality of immediacy was almost certainly a key attraction. 
Nineteenth century promenades that were created in other American cities varied in their locational characteristics. The Dutton Mall in industrial Lowell MA, took its alignment from the Merrimack Canal, initially occupying a thirty-eight foot wide corridor between the canal and a parallel street, later narrowed to twenty-eight feet. Its partner, the Shattuck Mall, bordered the Northern Canal in the same city. Both exhibited carefully designed landscapes featuring double rows of shade trees, and both were heavily used by factory workers as recreational and social venues (Malone and Parrott, 1998). The alignment of the canals shaped the layout of the promenades, which were viewed as showpieces attesting to the city's self-proclaimed image as the "Venice of America". Much of the length of these canal promenades was bordered by pleasant residential streets, home to both wealthy and working classes. The proximity of residential neighborhoods ensured that the canalside walks were readily accessible to a diverse group of inhabitants, and contemporary accounts indicate that they were heavily used. A later addition known as the Canal Walk was constructed atop a high, walled, thousand-foot long embankment at the intersection of the Northern Canal and the Merrimack River, offering promenaders superb views of the river below (Malone and Parrott 1998). Walking for pleasure and social engagement demanded routes that were diverse and interesting, relatively unimpeded, and lengthy enough for unhurried social encounters that would have been unacceptable in other settings. Consequently the proximity of water views, the natural linear alignment of the watercourses and their generous lengths, offered ideal conditions for the Lowell promenades.

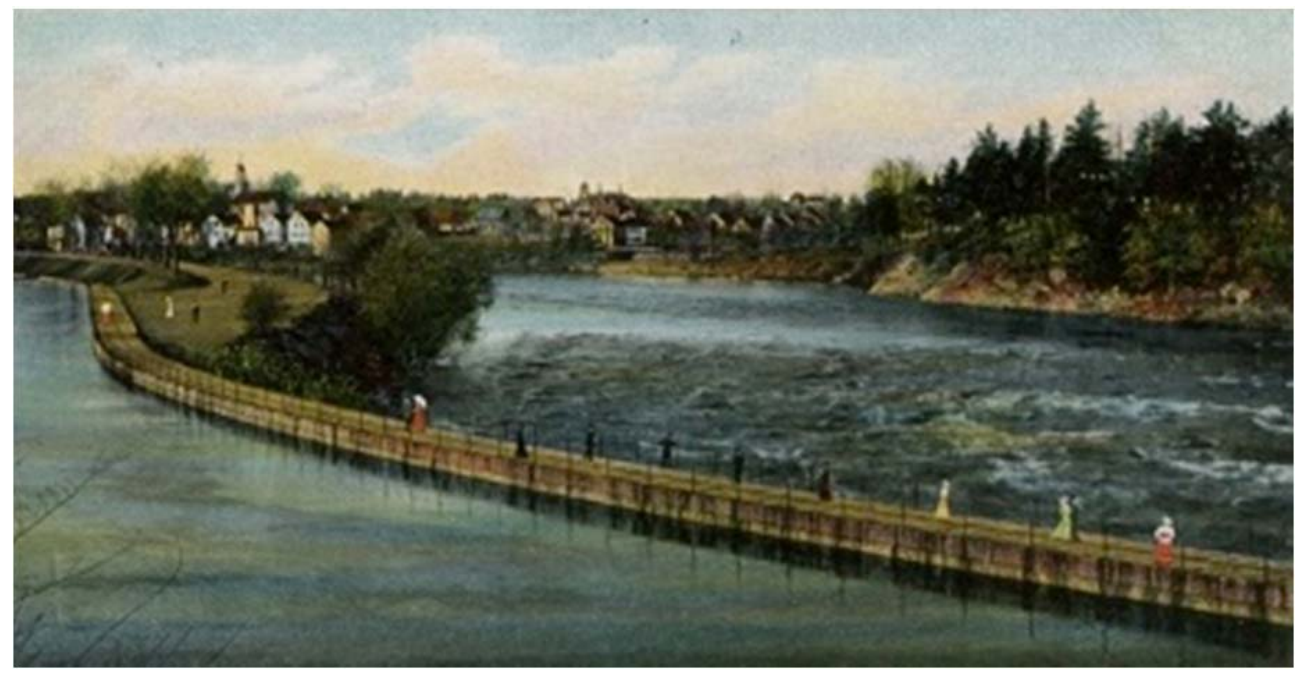

Fig. 16. Pedestrians along Canal Walk, Lowell, Mass. With Northern Canal on left and Merrimack River on right. Metropolitan News Co., Boston, Mass. [1902-1907].

Brooklyn and New York promenades of the early nineteenth century are welldocumented. They consisted of four types: off-street promenades such as the Battery, Brooklyn Heights, and Fort Greene concourses; street promenades, where the sidewalks of fashionable streets such as Fifth Avenue and Broadway were regularly appropriated by members of the affluent upper class for the dual purposes of social display and encounter; formal pedestrian concourses within public parks, such as the Mall in Central Park; and the Eastern and Oceanview parkway promenades that served as local recreational spaces 
as well as linear park connectors between Prospect Park and other recreational venues to the east and south respectively.

Originally the Brooklyn Heights promenade occupied a broad strip of land above the Brooklyn waterfront, land that was privately owned but widely used as a quasi-public space offering a pleasant bucolic setting with excellent views across the river to the New York harborfront. The fact that it was bordered by residential neighborhood streets to the east made it highly accessible, with contemporary estimates of usage of between several hundred to a thousand people daily. An 1820 proposal to formalize its status as an already popular venue for leisurely strolling and socializing, anticipated that this designation and associated improvements would also contribute to an appreciation in the values of adjacent real estate. The proposal called for a promenade varying in width from $75 \mathrm{ft}$. to $150 \mathrm{ft}$. and approximately $1 / 2 \mathrm{mi}$. long, with amenity features such as shade trees and benches. However despite ample public support for the idea over a number of years, it did not come to fruition, eventually losing out to the promenade and park that was established at Fort Greene in 1847 (Bluestone, 1987).
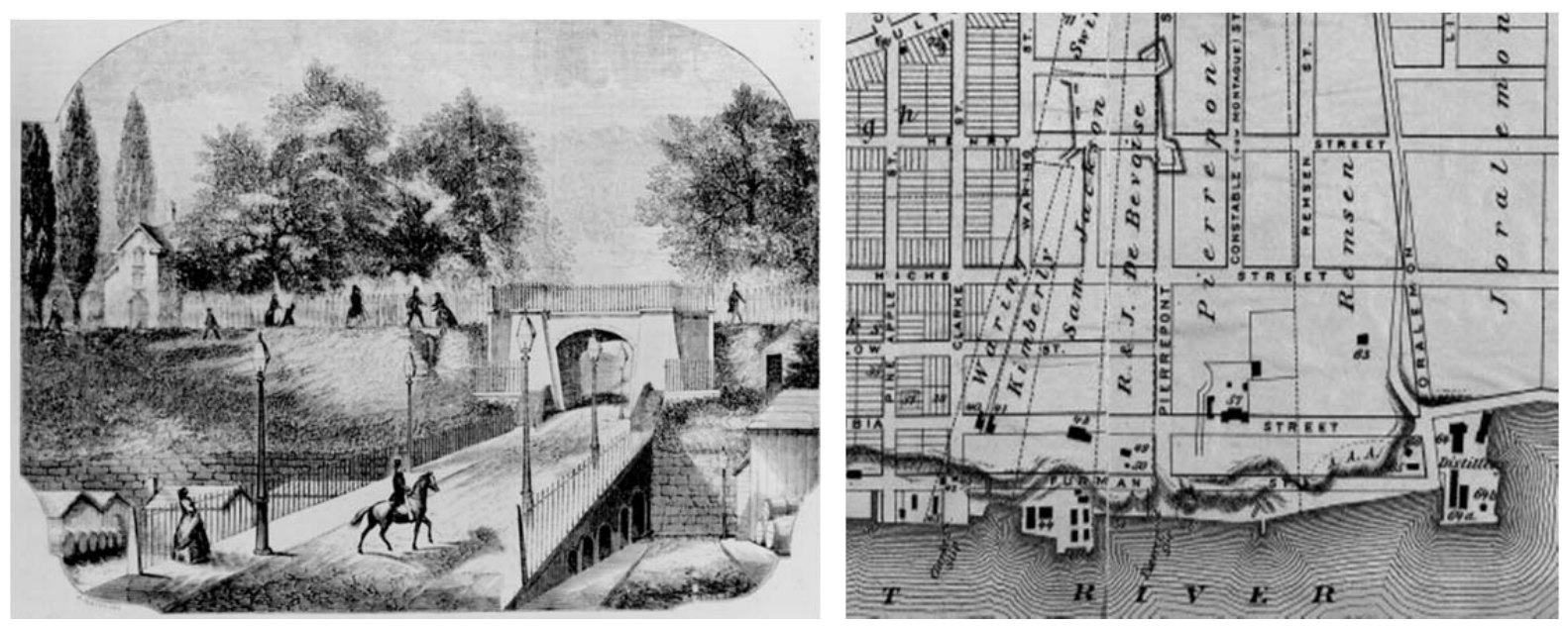

Fig. 17 (left). View of promenade along the bluff, Brooklyn Heights, New York. Gleason's Pictorial DrawingRoom Companion, 1854.

Fig. 18 (right). Village of Brooklyn, 1816. The Brooklyn Heights promenade was located along the hachured bluff overlooking the river. The outline of the fortifications of Fort Greene is visible in the upper left.

In Central Park Frederick Law Olmsted and Calvert Vaux designed a half-mile long formal promenade lined with benches to offer comfortable opportunities for respite and observation of the energetic flow of pedestrians who enlivened the Mall. Double rows of elm trees were chosen for their lofty stature and spreading canopy at maturity, which had the dual effects of not only providing shade, but as importantly, defining the spatial volume of the promenade corridor at a scale appropriate to its breadth. The concourse was located well within the park boundaries, and its alignment was deliberately deflected from the parallel streets that bordered the rectilinear park, in order to separate it from the urban context and embed it more effectively in the naturalized landscape that characterized the park. Olmsted identified a number of design criteria for the Central Park Mall which were consistent with many historic precedents. He determined that a successful promenade should be: at least $1 / 2$ mile in length (and ideally longer); a minimum of $150 \mathrm{ft}$. in width; straight in alignment; as level as possible; uninterrupted by crossstreets; shaded in the afternoon; and oriented so as to avoid the afternoon sun shining in 
the faces of promenaders. In addition, he indicated that service traffic should be prohibited on the concourse to ensure the amenity of recreational users on foot, horseback, or in carriages (Olmsted, 1973: 387).

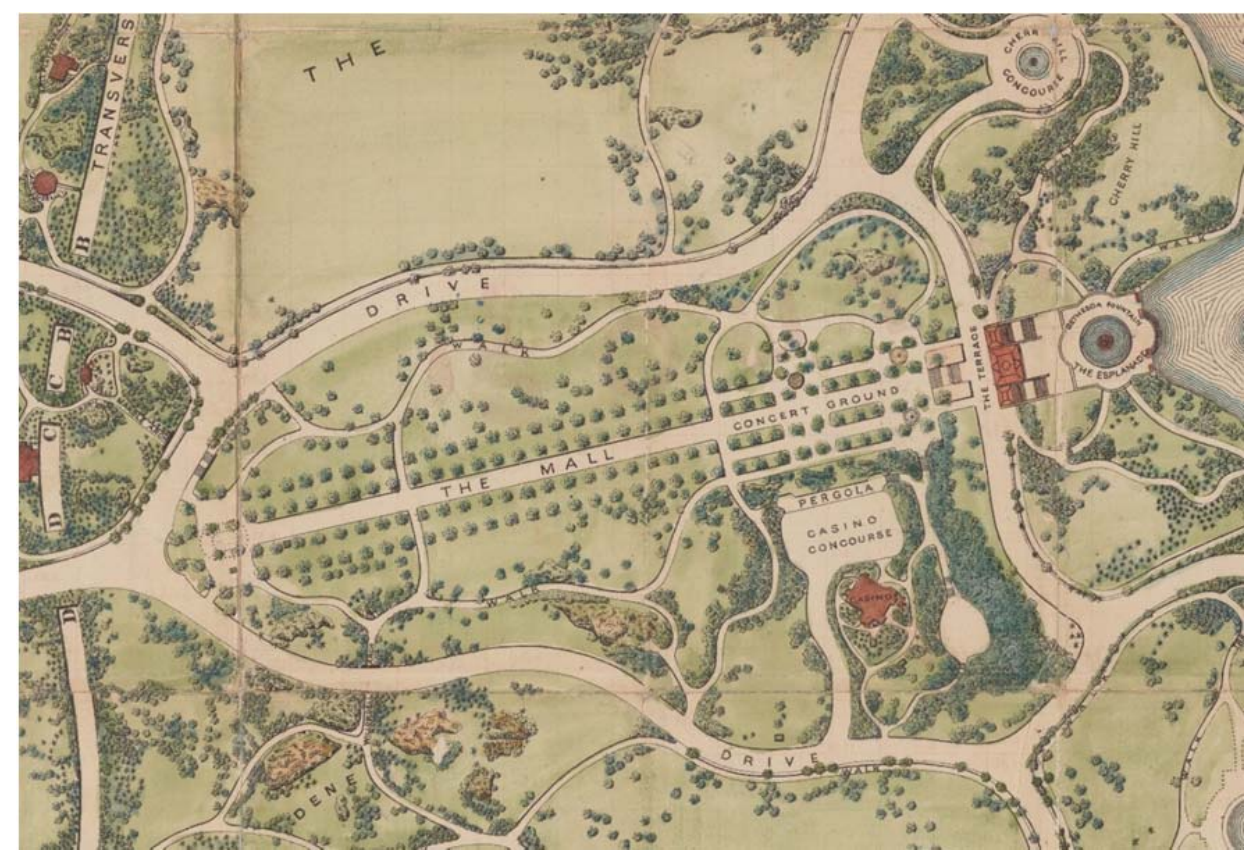

Fig. 19. Detail of The Mall from "Map of the Central Park", 1873.

The location of the Mall within the historic confines of Central Park ensured its survival until the present day, and it remains an enormously popular venue for strolling, peoplewatching, and informal performances of all kinds, attesting to the effectiveness of the original spatial framework, which remains intact. Even the flanking rows of elm trees, so important to the scale and character of the promenade space, have been carefully preserved in the face of the ongoing threat of Dutch elm disease, which has eradicated most American elms throughout the country.

The Eastern and Oceanview parkways that were created in Brooklyn in the 1870s were envisioned by Olmsted as key connectors in a metropolitan greenspace system, joining public parks at a regional scale and simultaneously serving local neighborhoods as linear parks and shared pleasure drives for pedestrians, riders, carriages, and later bicyclists. While initially laid out for the most part within undeveloped countryside, these wide boulevards were intended to promote residential development on their borders, and over time they were successful in this regard. Development along the parkways was primarily residential and numerous intersecting streets facilitated access from adjacent neighborhoods. With relatively high development densities lining the corridors the broad landscaped parkway median effectively acted as a continuous "front yard" for the series of neighborhoods adjoining it. In her comprehensive study of the parkways, Macdonald (20I2) observes that they currently function as much more than linear promenades, supporting a wide range of local social and recreational uses, in addition to their primary role of accommodating leisurely movement. 


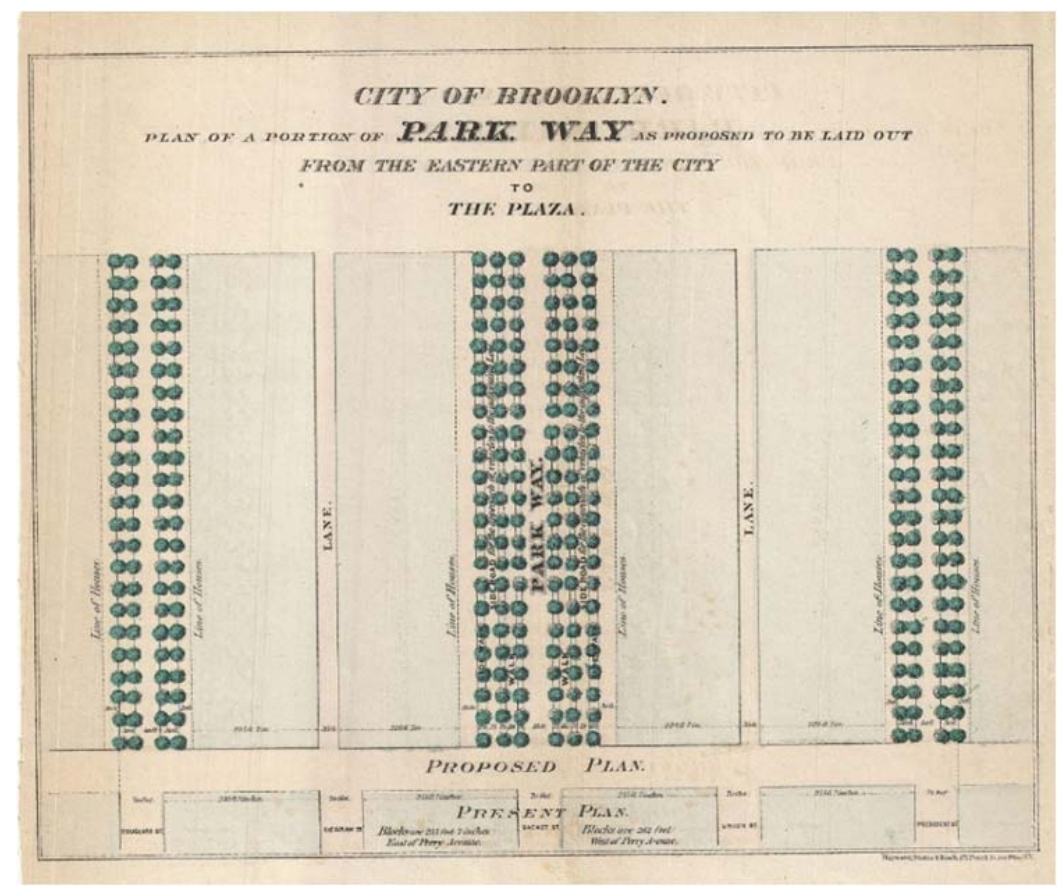

Fig. 20. Plan of Eastern Parkway, F.L.Olmsted and C.Vaux, Manual of the Common Council of the City of Brooklyn, 1868.

The layout of both parkways was similar, with a central carriageway for pleasure driving, flanked on either side by tree lawns, wide pedestrian malls and narrow side roads that provided access to the properties that fronted the boulevards. Careful separation of the various circulation systems prevented potential conflicts that could diminish the pleasure of the parkway experience. Landscaped setbacks of 30-32 ft. were required on all of the lots that lined the parkways, a strategy that Olmsted employed in order to blur the boundaries between public and private landscapes and to enhance the parklike character of the boulevards. The continuity of the parkways was preserved by limiting arterial cross streets, while midblock alleys behind the parkway lots assumed much of the obtrusive service traffic that otherwise would have shared the $25 \mathrm{ft}$. wide residential access roads flanking the boulevards. Each parkway was shaded by six rows of trees, with additional amenity features such as lighting, benches, and water fountains installed in later years (Macdonald, 2012).

Macdonald (2012: 224) also notes the success of the Eastern and Oceanview parkways as contemporary social spaces, observing that their linearity fosters mixing between residents of different neighborhoods. She cites several other key spatial features that distinguish the parkways and lend them a quality of unity, including the uniformity of the street section, the density of housing that lines the street frontages and defines a consistent spatial volume and scale, the continuity of the pedestrian malls, the regularity of the tree planting, and the presence of numerous benches throughout. Above all, the ability of these corridors to adapt to changing social and cultural circumstances is an enormous asset that has ensured their longevity and continued relevance to contemporary public life. This attests to the robustness of the original spatial framework, which continues to contain, support, but not determine, the nature of the activities that occur within it. 


\section{Persistent Typological Features}

Comparison of eighteenth century and nineteenth century European and American promenade precedents reveals consistencies in a number of their physical and spatial characteristics, many of which appear to have influenced both the functionality and the appeal of the spaces. The locations of promenades had significant effects on their accessibility. While the earliest European promenades were established outside city walls where undeveloped land offered a welcome escape from crowded urban streets, over time landscaped promenade settings at first enjoyed only outside the city were recreated in gardens and parks within the urban fabric, often in locations where proximity to water bodies added to their amenity. These landscaped settings offered restorative experience as well as social opportunities, qualities which were reconceived in more urban form in street promenades, where generous shade tree plantings separated pedestrian concourses from carriageways.

As promenades became more openly available to all members of the public and not only to affluent carriage owners, locations that were central to densely populated residential areas or active commercial districts offered convenient access to large numbers of people, a condition that augmented levels of use. Regardless of rural or urban setting however, sites that afforded appealing and diverse views were highly favored. Topography was a consideration as well; not surprisingly, promenades were almost always situated on relatively flat terrain that encouraged ease of movement for pedestrians and carriages alike.

In addition to the location of a promenade, accessibility was also affected by its relationship to the surrounding street pattern. This was particularly true of the street promenades and parkways, where multiple intersecting local streets formed direct connections into adjacent neighborhoods. On belt boulevards and parkway promenades, limited arterial crossings reduced connectivity to the broader street system and mitigated the disruptive impacts of non-recreational traffic that moved at higher speeds. This served to insulate the street promenade from district scale traffic, while enhancing its accessibility to local residents. Park promenades often were not linked directly to the surrounding street system, Central Park being one example. In this case the Mall was embedded in the middle of the park, drawing its activity not from connection to a busy street, but from its attraction as a nexus of active and passive public interaction for the many park-goers who gravitated to it.

The alignments and dimensions of eighteenth century and nineteenth century promenades varied according to context. Promenades located on the site of a former pall mall ground or anchoring the axial spine of a formal garden were straight, while others were circuitous, for example following the alignment of rampart walls. Regardless of alignment however, providing an uninterrupted linear flow of movement was of paramount importance. Walkways were typically wide enough to accommodate the passage of large numbers of people comfortably, and while lengths varied, most offered extended strolls of a half mile or more, since with increased length came additional opportunity for diverse scenery and experience. The need for a long promenade route was especially relevant in early years due to a social convention that discouraged participants from pausing. This had a functional rationale in the case of the "parade", or carriage promenade, since stopping a carriage would impede the progress of all of those who followed. However this convention was equally in force among pedestrians. Promenades in mid-nineteenth century New York for example, were among the few public venues where respectable persons of both sexes could mix without censure. However these interactions were only 
considered acceptable under specific conditions, among them the requirement that movement, while slow and sedate, be constant. If a conversation was to be maintained, it must be accomplished while both parties were in motion (Scobey, 1992), and the longer the promenade route, the more opportunity was afforded for leisurely exchanges.

The spatial scale and demarcation of the promenade corridor were important factors influencing amenity. From earliest iterations, shade tree plantings were requisite amenity features. Typically planted in single, double, or triple rows, they not only defined the spatial boundaries of the promenade and moderated the microclimate, in addition the closely spaced plantings delineated the various functional corridors within multi-use promenades, for example providing spatial separation between pedestrian concourses and carriageways. The continuous overhead canopy afforded by rows of trees also had the effect of mitigating spatial scale so that even wide concourses were experienced as more intimate spaces than otherwise would have been the case. Uninterrupted building facades that lined street promenades also yielded consistent spatial enclosure that supported linear movement along the corridors. And these well-populated residential, mixed residential/commercial, or civic buildings housed diverse patrons to activate the adjacent promenade spaces.

\begin{tabular}{|c|c|c|c|c|c|c|c|c|c|c|c|c|}
\hline Era & Country & city & Promenade Name & Location & Condition & Pedestrian zone & Length & ROW & Mall Width & Edge Condition & Adjacencies & Amenity Features \\
\hline & & & & & & & & & & & & \\
\hline \multirow[t]{7}{*}{$17 \mathrm{C}$} & France & Paris & Mail de l'Arsenal & Arsenal & off-street & concourse & $600^{\prime}$ & $80^{\prime}$ & $20^{\prime}$ & canal & urban & shade trees \\
\hline & & & Cours la Reine & bet. Seine \& Tuileries & central carriageway & parallel concourse & $.90 \mathrm{mi}$. & $130^{\prime}$ & & $\begin{array}{l}\text { riverside/garden } \\
\end{array}$ & urban & shade trees \\
\hline & & & Tuileries Garden & Tuileries & off-street & concourse & $.2 \mathrm{mi}$. & & $90^{\prime}$ & garden & urban & shade trees \\
\hline & & & Belt-boulevards & former ramparts & central carriageway & parallel concourse & various & & $115^{\prime}$ & boundary wall & resid./comm. & shade trees \\
\hline & & & Ave. des Tuileries & bet. Tuileries and Etoile & central carriageway & parallel concourses & $.5 \mathrm{mi}$ & $260^{\prime}$ & & & countryside & shade trees \\
\hline & England & London & The Mall & St. James Park & off-street & concourse & $.5 \mathrm{mi}$. & & $130^{\prime}$ & park & institutional & shade trees \\
\hline & & & & & & & & & & & & \\
\hline \multirow[t]{9}{*}{$18 \mathrm{C}$} & United States & Washington & The Mall & Federal core & off-street & concourse & $1.5 \mathrm{mi}$. & & $300^{\prime}$ & bordering streets & institutional & shade trees \\
\hline & & Boston & The Mall & Boston Common & off-street & concourse & $1.5 \mathrm{mi}$. & & $90^{\prime}$ & bordering streets & resid./instit. & shade trees \\
\hline & & New York & Battery Promenade & waterfront & off-street & concourse & $.35 \mathrm{mi}$. & & $10-12^{\prime}$ & shoreline & resid./comm. & shade trees \\
\hline & Ireland & Dublin & Gardiners Mall & city core & street & central concourse & $.25 \mathrm{mi}$. & $150^{\prime}$ & $50^{\prime}$ & bordering streets & resid./comm. & shade trees, \\
\hline & & & & & & & & & & & & lighting \\
\hline & Germany & Berlin & Unter den Linden & bet. Palace \& Brandenbu & street & central concourse & $.6 \mathrm{mi}$. & $200^{\prime}$ & $55^{\prime}$ & bordering streets & resid./comm. & shade trees \\
\hline & & & & Gate/Tiergarten & & & & & & & & \\
\hline & England & London & Rotten Row, Hyde Pk & Hyde Park & off-street & parallel concourses & $.85 \mathrm{mi}$ & & $60^{\prime}$ & park & urban & shade trees \\
\hline & & Bath & Grand Parade & health resort & off-street & concourse & $538^{\prime}$ & & $52^{\prime}$ & riverside & urban/country & shade trees \\
\hline \multirow[t]{13}{*}{$19 \mathrm{C}$} & France & Paris & Ave L'Imperitrice & city core & street & parallel concourses & & $390^{\prime}$ & $39^{\prime}$ & bordering streets & resid./comm. & shade trees \\
\hline & & & & & & & & & & & & \\
\hline & United States & Brooklyn & Brooklyn Heights Prom & Brooklyn Heights & off-street & concourse & $.5 \mathrm{mi}$. & & $75-150^{\prime}$ & bordering streets & residential & shade trees \\
\hline & & & Eastern Parkway & bet. Prospect Park/ & & parallel concourses & $2.5 \mathrm{mi}$ & $200^{\prime}$ & $35^{\prime}$ & bordering streets & residential & shade trees, benches, \\
\hline & & & & Ralph Ave. & & & & & & & & lighting, landscaping \\
\hline & & & Oceanview Parkway & bet. Prospect Park/ & street & parallel concourses & $5.5 \mathrm{mi}$. & $210^{\prime}$ & $30^{\prime}$ & bordering streets & residential/co & trees, benches, lighting, \\
\hline & & & & Coney Island & & & & & & & & landscaping \\
\hline & & & Coney Island concourse & Beachfront & off-street & concourse & $.5 \mathrm{mi}$. & & & shoreline & commercial & \\
\hline & & New York & Fifth Ave & Manhattan & street & sidewalk & & & & bordering streets & resid./comm. & \\
\hline & & & Broadway & Manhattan & street & sidewalk & & & & bordering streets & commercial & \\
\hline & & & The Mall & Central Park & off-street & concourse & $.5 \mathrm{mi}$. & & $150^{\prime}$ & park & residential/col & shade trees, benches \\
\hline & & Lowell MA & Dutton//Shattuck Mall & Merrimack Canal & off-street & concourse & $.5 \mathrm{mi}$. & & $28^{\prime}$ & canal/street & residential & shade trees, landscaping \\
\hline & & & Canal Walk & Northern Canal & off-street & concourse & $.75 \mathrm{mi}$. & & $20^{\prime}-22^{\prime}$ & canal/street & residential & shade trees, landscaping \\
\hline
\end{tabular}

Table I. Summary of physical and spatial characteristics of selected promenade precedents. Dimensions are approximate.

Tree plantings were ubiquitous features in every promenade precedent other than the Fifth Ave. and Broadway examples in New York City, where sidewalks were regularly appropriated for specific, limited time periods by elites, in settings that lacked the typical amenity features of trees and pleasing views but offered in their place, the appeal of a fashionable setting and crowds of onlookers to admire and validate the display of class distinction. In other promenades, trees were highly valued for the welcome shade they cast on walkways in the spring and summer months, and for conveying a restorative natural quality that distinguished the settings from their urban surroundings. Shade trees were ever-present, but other amenity features were common as well. Benches, lighting 
and other forms of street furniture were often added to nineteenth century promenades to enhance comfort and safety and to encourage people to linger on the sidelines. The presence of benches along the edges of pedestrian concourses provided opportunities for respite and at the same time afforded ideal vantage points for observing the leisurely flow of pedestrians and carriages.

\section{Conclusion}

This research focused on two questions: Firstly, are there certain formal qualities that enhance accessibility, activity, and amenity, and therefore contribute to the success of the promenade as a public space? And secondly, are there are particular physical and spatial conditions that have persisted, contributing to the capacity of the promenade to endure over centuries? Analysis of eighteenth and nineteenth century precedents in Europe and the United States suggests that easy access, abundant activity, and comfortable conditions for moving at a leisurely pace all contributed to the appeal of popular promenades. These factors influenced whether people would be inclined initially to engage the public life of the promenade, and thereafter, whether they might choose to return on a regular basis. Direct access and close proximity were particularly important factors for pedestrians, reducing the distance travelled on foot to reach their destination. Activity levels were of consequence as well. Unlike informal footpaths that may have been available elsewhere in gardens or parks, where walkers might have willingly and even preferably distributed themselves so as to reduce congestion and enhance their experience of a landscape setting, the consistent aim of promenade patrons has been "to see and be seen". The promenade was a venue predicated on the experience of being "in public", that is, being surrounded by others of like mind, and sharing a common setting, whether for active engagement or simply for vicarious enjoyment through observation of the passing throngs. A promenade that regularly failed to attract adequate numbers of people would scarcely have fulfilled expectations and consequently, preferred locations tended to be within or nearby densely populated residential neighborhoods or busy commercial districts. Finally, amenity was a critical factor in the appeal of the promenade, whether it be derived from shade to moderate warm temperatures, comfortable spatial scale, adequate dimensions to accommodate crowds without hindering the flow of movement, access to pleasing views, relatively flat and uninterrupted linear corridors, or provision of supportive features such as lighting and benches.

The analysis also indicates that certain shared physical and spatial characteristics have persisted among geographically dispersed promenades over a timespan of several hundred years. Typological features such as location, connectivity, adjacency, alignment, dimensions, scale, and amenity features have contributed to the qualities of accessibility, activity, and comfort that have attracted people to promenades and supported their popularity over time. The research confirms as well that nineteenth century American promenades were legitimate successors to earlier European precedents, exhibiting similarities in physical and spatial attributes that place them squarely within a typological tradition.

These findings raise further questions: Does the promenade tradition persist in some form in the United States, in a contemporary iteration of the type? Is there still demand for the activities of "seeing and being seen" in the American public realm? Have disjunctions effected in the post-industrial era, whether evidenced by functionalist degradation of the pedestrian realm, claims of a diminished and devalued public life, or 
abandonment of the real world for a virtual realm, eroded the viability of a public space type that endured for centuries? Evidence suggests that despite the damage wrought on the urban public domain by these twentieth century forces, the promenade tradition has re-surfaced on the post-industrial, post-functionalist American urban waterfront and on other repurposed linear corridors situated at the hearts of American cities. As ongoing processes of urban redevelopment yield additional promenade opportunities, understanding the typological features that have contributed to the success of historic precedents could be a valuable asset in designing these contemporary public spaces. Further research is currently underway to assess whether recently developed American promenades conform to the typological attributes of their eighteenth century and nineteenth century forebears, whether the physical and spatial conditions that characterize the traditional promenade are compatible with post-industrial urban morphologies, and whether the functions of traditional promenades are adaptable to the diverse demands placed on the public realm in contemporary America.

\section{References}

Alphand, Jean-Charles-Aldolphe. (1984) Les Promenades de Paris : histoire--description des embellissements--dépenses de création et d'entretien des Bois de Boulogne et de Vincennes, Champs-Élysées--Parcs--squares--boulevards--places plantées. Princeton, N.J.: Princeton Architectural Press (reprint of original, Paris: J. Rothschild, I867-73).

Bluestone, D. M. (1987). From promenade to park: The gregarious origins of Brooklyn's Park Movement, American Quarterly, 39(4), 529-550.

Cleary, Richard (2002). Making breathing room: Public gardens and city planning in eighteenth century France, in Hunt, J. D., Conan, M., \& Goldstein, C. Tradition and innovation in French garden art: Chapters of a new history. Philadelphia: University of Pennsylvania Press.

Corbusier L, Etchells F. The city of tomorrow and its planning. London: J. Rodker; 1929.

Darin, Michael (2000). French belt boulevards. Urban Morphology, 4(I), 3-8.

Domosh, M. (1996). Invented cities: The creation of landscape in nineteenth-century New York \& Boston. New Haven: Yale University Press.

Domosh, Mona (1998). Those 'gorgeous incongruities': Polite politics and public space on the streets of New York City. Annals of the Association of American Geographers, 88(2), 209-226.

Girouard, M. (1985). Cities \& people: A social and architectural history. New Haven: Yale University Press.

Kostof, Spiro (1991). The city shaped: Urban patterns and meanings through history. London: Thames and Hudson.

Larkham, P. J. (2000). Promenades in English towns. Urban Morphology, 4(2), I06-I06.

Lawrence, H. W. (1988). Origins of the tree-lined boulevard. Geographical Review, 78(4), 355-374.

Macdonald, E. (20I2). Pleasure drives and promenades: The history of Frederick Law Olmsted's Brooklyn parkways. Chicago, III: Center for American Places at Columbia College.

Malone, P. M., \& Parrott, C. A. (1998). Greenways in the industrial city: Parks and promenades along the Lowell canals. IA. The Journal of the Society for Industrial Archeology, 19-40.

Moudon, Anne Vernez (1987). The research component of typomorphological studies. AIA/ACSA Research Conference Proceeding. Boston.

Olmsted, Frederick Law Sr. (1875). Report on a promenade. New York City Department of Public Parks, Document No. 67. Reprinted in Olmsted, Frederick Law Jr. and Theodora Kimball eds. (1973). Forty years of landscape architecture: Central Park, Cambridge: MIT Press.

Rabreau, Daniel (199I). Urban walks in France in the seventeenth and eighteenth centuries, in Mosser, Monique \& Georges Teyssot, eds. The architecture of western gardens: A design history from the renaissance to the present day. Cambridge, Mass: MIT Press. 
Reps, John W. (199I) Washington on view: The nation's capital since 1790. Chapel Hill: University of North Carolina Press.

Rogers, Elizabeth B. (200I) Landscape design: a cultural and architectural history. New York: Abrams.

Scobey, D. (1992). Anatomy of the promenade: The politics of bourgeois sociability in nineteenthcentury New York. Social History, 1 7(2), 203-227.

\section{Image Sources}

Fig. I View of the Arsenal Mall, Turgot map of Paris, 1739.

Turgot map of Paris, Kyoto University Library. Wikimedia Commons. Retrieved July 6, 2017 from https://commons.wikimedia.org/w/index.php?title=Turgot_map_of_Paris,_Kyoto_University Library\&oldid=173229193 Public domain (PD-1923)

Fig. 2 Aerial view of Cours la Reine, bordering the Seine River, Paris. Turgot map of Paris, 1739.

Turgot map of Paris, Kyoto University Library. Wikimedia Commons. Retrieved July 6, 2017 from https://commons.wikimedia.org/w/index.php?title=Turgot_map_of_Paris,_Kyoto_University Library\&oldid=|73229|93 Public domain (PD-1923).

Fig. 3 View of central promenade in Tuileries Garden, Paris I8C. Engraving by Perelle.

Wikipedia Commons. Retrieved 17:26, July 6, 2017 from https://en.wikipedia.org/wiki/Tuileries_Garden\#/media/File:S7001316.JPG Public domain (PD-1923)Fig. 4 View of the Mall in St. James Park. Courtesy of Roy Rosenzweig Center for History and New Media, George Mason University and the National Endowment from the Humanities.

Retrieved Sept. 19, 2017 from https://mallhistories.tumblr.com/post/I24759982270/do-you-knowhow-the-national-mall-came-to-be Content licensed under (CC-BY).

Fig. 5 Detail of 1814 map of Boston by John Groves Hale. Courtesy of Norman B. Leventhal Map Center Collection, Boston Public Library

Retrieved July 6, 2017 from https://collections.leventhalmap.org/search/commonwealth:x059cc38s. Content licensed under (CC-BY-NC-SA )

Fig. 6 Early view of the Battery Promenade, New York City, late 18C. Joseph Drayton, artist.

Art and Picture Collection, The New York Public Library. (1903). A view of the Battery and Harbour of New York, and the Ambuscade Frigate. Retrieved July 6, 2017 from http://digitalcollections.nypl.org/items/5I0d47el-0c2e-a3d9-e040-e00al8064a99 Public domain.

Fig. 7 John Bachmann, Bird's Eye View of Central Park, 1863. Hand-colored lithograph.

Lionel Pincus and Princess Firyal Map Division, The New York Public Library. (1863). Central Park Retrieved Sept 22, 2017 from http://digitalcollections.nypl.org/items/5 I0d47e3-cbd4-a3d9e040-e00a I8064a99 Public domain.

Fig. 8 Plan and section drawings of Boulevards des Batignolles and Italies. Les Promenades de Paris. JeanCharles-Aldolphe Alphand, 1867-73. Source: Bibliotheque Nationale de France.

Retrieved Sept 22, 2017 http://gallica.bnf.fr/ark:/I2148/bpt6k310316c Public domain.

Fig. 9 Detail of Gardiner's Mall, from An Exact Survey of the City and Suburbs of Dublin by John Roque, 1756. Source: Bibliotheque Nationale de France.

Retrieved Sept 22, 2017 http://gallica.bnf.fr/ark://2I48/btv/b5967586qPublic Domain.

Fig. 10 Perspective view of Sackville Street and Gardiner's Mall in Dublin, Ireland in the 1750s, by Oliver Grace.

Retrieved July 6, 2017 from https://commons.wikimedia.org/wiki/File:Sackville_St_and_Gardiner\%27s_Mall in the 1750 s_by_Oliver_Grace.jpg Public domain (PD-1923)

Fig. I I Plan of the City and Garden of Versailles designed by Andre le Notre, from an I8C engraving.

Retrieved Sept. 22, 2017 from https://commons.wikimedia.org/wiki/File:Versailles,_Garden_Plan.jpg Public Domain \{PD$\underline{1923}\}$ 
Fig. 12 The Mall as proposed by Pierre L'Enfant I 790, from the original. Corps of Engineers, U.S. Army, Office of Public Buildings and Grounds, [190I]. Courtesy of Library of Congress, Geography and Map Division.

United States Office of Public Buildings And Grounds, L'Enfant, P. C., Owen, F. D., Bingham, T. A. \& United States Army. Corps Of Engineers. (I79I) [The Mall as proposed by Pierre L'Enfant 1790: from the original: Washington D.C]. [Washington: Corps of Engineers, U.S. Army, Office of Public Buildings and Grounds] [Map] Retrieved Sept 22, 2017 from the Library of Congress, https://www.loc.gov/item/886909/6/ Public domain.

Fig. 13 McMillan Plan showing design for the Mall 190I, Washington DC. Source: National Capital Planning Commission.

Retrieved July 6, 2017 from https://commons.wikimedia.org/wiki/File:McMillan_Plan.jpg_Public domain (PD-1923)

Fig. I 4 Castle Garden in the Battery, New York City, 1869. Theodore August Liebler, artist. Source: The New York Public Library Digital Collections.

Art and Picture Collection, The New York Public Library. Retrieved July 6, 2017 from http://digitalcollections.nypl.org/items/510d47el-0c2a-a3d9-e040-e00al8064a99 Public domain.

Fig. I5 Castle Garden landing for emigrants, Barge Office, Battery, ca. 1869. Source: New York Public Library Digital Collections.

Art and Picture Collection, The New York Public Library. Retrieved July 6, 2017 from http://digitalcollections.nypl.org/items/510d47el-0c28-a3d9-e040-e00a 18064a99 Public domain.

Fig. 16 Canal Walk, Lowell, Mass. Metropolitan News Co., Boston, Mass. [1902-1907]. Courtesy of Kheel Center for Labor-Management Documentation \& Archives. Image Library, ATHM Accession Number: 0000.1574.3, Cornell University. Public Domain.

Fig. 17 View of promenade along the bluff, Brooklyn Heights, New York. Gleason's Pictorial Drawing-Room Companion (Boston, 1854). Source: National Archives and Records Administration.

Retrieved July 6, 2017 from https://commons.wikimedia.org/wiki/File:Brooklyn_heights_drawing_1854.jpg_Public domain (CC-PD-Mark) (PD US Government)

Fig. I8 Map of the village of Brooklyn in 18/6, Jeremiah Lott.

Collection of the Brooklyn Historical Society. Retrieved Sept. 22, 2017 from https://brooklynhistory.org/library/wp/library-collections/maps/ Public Domain.

Fig. 19 Detail from "Map of the Central Park", I873. Courtesy of the New York Public Library Digital Collections.

Lionel Pincus and Princess Firyal Map Division, The New York Public Library. (1873). Retrieved July 6, 2017 from http://digitalcollections.nypl.org/items/4eel4540-3569-0134-fa8200505686 a 5 Ic Public domain.

Fig. 20 Plan of Eastern Parkway, F.L.Olmsted and C.Vaux, Manual of the Common Council of the City of Brooklyn, 1868.

Retrieved July 6, 2017 from https://commons.wikimedia.org/wiki/File:1868_Vaux_and_Olmstead\%27s_Layout_Map_of Eastern_Parkway, Brooklyn, New York__Geographicus - EasternParkway-bishop1868.jpg Public domain (PD-1923) 